\title{
Owner-Architect-Contractor: Another Eternal Triangle
}

\author{
Justin Sweet*
}

The construction industry is a fertile breeding ground for disputes. Large amounts of money are at stake, and the highly competitive building business involves great risks. More than the usual amount of contract interpretation problems occur because of the complexity of a building operation. Many, but far from all, of these disagreements are handled by arbitration. ${ }^{1}$

Building contract disputes often involve the contractor and the architect. This Article will discuss the power of the architect to affect the legal relations of the owner with respect to the contractor. In other words, under what conditions will the conduct of the architect in his dealings with the contractor result in liability to the owner? The analysis will deal with the private contract and a privately hired architect. If a case cited involves a public contract, the proposition for which it is cited does not depend upon whether the contract is private or public. Cases may be cited which deal with engineers. If a private engineer is retained for a given job, the principles are analogous. The Article will be divided into two main parts: Part I will deal with the power of the architect to bind the owner in contract.

*Visiting Associate Professor of Law, University of California, Berkeley.

1 Legislation has encouraged a great expansion in the use of arbitration to settle disputes. While earlier the use of arbitration was hindered by poorly drafted clauses, the American Institute of Architects Standard Contract contains an effective arbitration clause. Form A-2, American Institute of Architects, General Conditions of the Contract, art. 40 (6th ed. 1951) [referred to hereinafter as the AIA Standard Contract], in AMIERICAN INSTITUTE of ARCHTTECTS, ARCHItectural Practice 127 (7th ed. 1953), and in Parker \& Adams, AIA Standard Contract Forars and THE Law 55 (1954). Permission has been granted by the AIA to quote a number of the articles used in its form contract.

Despite the development of arbitration, the reports still contain a sizeable amount of construction contract litigation. In part this is due to the great number of these disputes. The building industry has flourished smce World War II. Almost every construction job develops some disagreement. Even if arbitration has channeled a great many of these controversies away from the courts, the huge number of disputes has still meant many lawsuits. Also, arbitration is not accepted as a dispute-settler quite as readily as is generally believed. The contractor may attempt to avoid arbitration and take his chances with a jury. Since there are procedural requirements which must be met to invoke arbitration, the arbitration clause may be waived. Scbmulbach v. Caldwell, 196 Fed. 16 (4th Cir. 1912); Geo. V. Nolte \& Co. v. Pieler Constr. Co., 337 P.2d 710 (Wash. 1959). Failure to plead the clause may be held waiver. Premier Petroleum Co. v. Box, 255 S.W.2d 29 (Tex. Civ. App.), error refused, 152 Tex. 321, 257 S.W.2d 105 (1953); Salzner v. Jos. J. Snell Estate Corp., 81 Utah 111, 16 P.2d 923 (1932).

Since many references to the AIA Standard Contract will be made in this Article, it should be noted that a new edition of the contract has been published in 1958 which as yet has not received the formal approval of all organizations which approved earher editions. References will be to the sixth edition of the contract since it is the one generally in use. 
Part II will discuss situations where the errors of the architect are chargeable to the owner. The Article will not deal with the conclusiveness of a certificate issued by the architect in the course of his duties. ${ }^{2}$

POWER OF ARCHITECT TO BIND OWNER CONTRACTUALLY

\section{A. Source of Architect's Authority}

The owner, architect, and contractor typically set forth their rights and duties with respect to each other in two separate agreements. Owner and architect have a contract, often oral, which generally provides that the architect will furnish plans and specifications and will exercise general supervision over the work to insure that the contractor performs in accordance with the contract. ${ }^{3}$ The contract between owner and contractor is more detailed and specifically limits the authority of the architect. This second contract, in the absence of other acts by the owner creating apparent authority beyond the terms of the agreement, is usually the source of the architect's authority. However, this instrument may not always control.

In Sando v. Kalberg, ${ }^{4}$ the contractor went to see the owner in order to enter into a contract to do some work. The owner instructed him to negotiate with the architect. The contractor went to the architect's office and refused to sign the contract unless certain changes were made. The architect promised that the owner would pay for certain extra work if it became necessary. The contractor signed the contract, the extra work had to be performed and the owner refused to pay, claiming the architect lacked authority. The court rejected the contention that the contract limited the authority of the architect, since the latter's promise had been made before the contract had gone into effect. The court noted that the owner had told the contractor to "negotiate" with the architect and had not limited his authority. Perhaps this act created apparent authority in the architect. However, the fact that the contract had not as yet been signed by the contractor does not change the fact that the contractor knew the architect's authority was to be limited. ${ }^{5}$ The conflict between the apparent authority

2 Annot., 54 A.L.R. 1255 (1928), supplemented by Annot., I10 A.L.R. 137 (1937). See generally Dabl v. Moss \& Son, Inc., 136 Conn. 147, 69 A.2d 562 (1949); Sikora v. Hogan, 315 Mass. 66, 51 N.E.2d 970 (1943); Walter v. Horwitz, 60 N.Y.S.2d 327 (Sup. Ct.), afjd, 271 App. Div. 802, 65 N.Y.S.2d 672 (2d Dep't 1946).

3 Form A-102, Agreement between Owner and Architect, arts. 1, 6, in ANrerican INSTITUTE OF ARCHITECTs, op. cit. supra note 1 , at 108.

4138 Wash. 247, 244 Pac. 576 (1926). To buttress this astounding decision the court found a ratification by failure to object and by making progress payments, although the change was of a technical nature and there was no showing of knowledge on the part of the owner. The case has never been cited.

5 Restatement (Second), Agency $\S 167$ (1958) provides: "If a person dealing with an agent has notice that the agent's authority is created or described in a writing which is intended for his inspection, he is affected by the linitations upon the authorty contained in the writing, unless misled by conduct of the principal." 
created by the owner's words and the yet unsigned contract should have placed the burden on the contractor of checking with the owner.

Despite the fact that the contract containing the terms of the architect's authority runs only between owner and contractor, third parties dealing with the architect cannot claim a lack of knowledge as to the scope of the architect's authority if they know of the existence of the owner-contractor agreement, and know that such a contract is likely to limit the architect's authority.

\section{B. Scope of Architect's Authority}

\section{Authority to Enter Into or Modify Existing Contracts}

Unless lie has specific authority to do so, the architect, by reason of his position, has no authority to enter into a contract on behalf of the owner.? This result conforms to custom and usage of the industry. A more difficult problem arises when the issue is the architect's authority to modify an existing contract.

The statement is often made that in the absence of specific authority to do so, ${ }^{8}$ the architect, as agent or judge of performance, ${ }^{9}$ has no authority

${ }^{8}$ McNulty v. Keyser Office Bldg. Co., 112 Md. 638, 76 Atl. 1113 (1910) (subcontractors); Sweeney v. Aetna Indem. Co., 34 Wash. 126, 74 Pac. 1057 (1904) (bonding company). Yet in another unfortunate Washington case, the court held a subcontractor could not rely upon the contract between owner and contractor which the subcontractor alleged conferred authority upon the architect to order material and labor. Stimson Mill Co. v. Feigenson Eng'r Co., 100 Wash. 172, 170 Pac. 573 (1918). Although there were better grounds for holding for the defendant, the court stressed the fact that the subcontractor was not a party to it, nor was it made for his benefit. Note that the subcontractor was attempting to expand the normal authority of the architect, which the court did not permit.

7 Umion Indem. Co. v. Acme Blow Pipe \& S. Metal Works, 150 Mass. 332, 117 So. 251 (1928) ; American Mailing Device Corp. v. Widener, 260 Pa. 375, 103 Atl. 875 (1918) ; Millard v. Parry, 2 Utah 2d 217, 271 P.2d 852 (1954); Bromley v. McHugh, 122 Wash. 361, 210 Pac. 809 (1922); Dodge v. McDonnell, 14 Wis. 600 (1861).

Nor has the architect authority to enter into a contract with a subcontractor. Campbell v. Day, 90 Ill. 363 (1878); Watts v. Metcalf, 23 Ky. L. Rep. 2189, 66 S.W. 824 (1902); McNulty v. Keyser Office Bldg. Co., supra note 6; Harrigan \& Reid Co. v. Hudson, 291 Mich. 478, 289 N.W. 222 (1939) ; Dunovant v. Taylor, 40 S.W. 326 (Tex. Civ. App. 1897) (even where architect authorized to let contract to general contractor); Vanderwerker v. Vermont Cent. Ry., 27 Vt. 125, 130 (1855); Schanen-Blair Co. v. Sisters of Charity, 77 Wash. 256, 137 Pac. 468 (1914). In the last case, the court stated: "In the absence of an express contract or compelling facts, it is never held as a matter of law that an architect has any implied power to purchase materials or to enter into a contract for or on behalf of the owner." Id. at 259,137 Pac. at 469.

8 Under article 15 of the AIA Standard Contract the architect may order changes orally or in writing if they are minor in nature and not inconsistent with the purposes of the building. If the change is not minor or involves extra cost the AIA Standard Contract requires a writing signed by owner and architect or signed by the architect and stating that the owner has authorized it.

If the architect is given authority to make alterations, the exercise must be reasonable. Dalstrom Metallic Door Co. v. Evatt Constr. Co., 256 Mass. 404, 152 N.E. 715 (1926).

${ }^{8}$ Some cases examine scope of authority in light of the provision making the architect the judge of performance. Article 38 of the AIA Standard Contract states he is in the first instance 
to modify a contract. ${ }^{10}$ While this general rule is unquestioned, contract modification problems may arise in analytically distinct situations.

A modification may consist of ordering work which is different from that called for by the contract. If this work or material is more expensive than that called for under the contract, the contractor will demand compensation beyond the contract price. This is called an "extra." This problem will be dealt with later. ${ }^{11}$

A modification situation may also arise when the owner refuses to pay the balance due under the contract, claiming the building does not conform to the plans and specifications. The contractor may assert that the architect either ordered or accepted the variation. If the architect has authority to make such changes, the owner must pay. If no such authority exists, the contractor's right to compensation for the work depends upon whether he has substantially performed under the original contract. Cases involving this issue have reached different results. Some courts have held the architect did have authority to modify ${ }^{12}$ while otler decisions faced with the

the interpreter of the contract and the judge of its performance. In this capacity, his decisions as to how work should be done bind the owner only if there are repugnant provisions or if the contract is silent, but not where the provision is susceptible to only one interpretation. Mallard, Stacy \& Co. v. Moody, 105 Ga. 400, 31 S.E. 45 (1898); Jaques v. Otto Nelson Co., 119 Me. 388, 111 Atl. 515 (1920); DeHoney v. Gjarde, 134 Wash. 647, 236 Pac. 290 (1925); cf. Drummond v. Hughes, 91 N.J.L. 563, 104 Atl. 137 (Ct. Err. \& App. 1918). While he cannot direct structural changes, it has been held that his directions as to how work should be done and approval as to material are binding on the owner. Hewitt v. Buchanan, 4 S.W.2d 169 (Tex. Civ. App. 1927). Accord, Croft v. H. M. Cohen Lumber \& Bldg. Co., 107 S.W.2d 1040 (Tex. Civ. App. 1937). Like the cases discussed in text at notes 12-13, infra, the cases where the owner has been held were those in which the issue was performance and the changes minor.

10 See, e.g., Monson v. Fischer, 118 Cal. App. 503, 5 P.2d 628 (1931) Brown v. Coffee, 17 Cal. App. 381, 121 Pac. 309 (1912) (cannot change term of payment from fixed price to day work); Fontano v. Robbins, 22 App. D.C. 253 (1903); Adlard v. Muldoon, 45 Ill. 193 (1867); Natchitoches Motor Co. v. Campbell, 17 La. App. 425, 136 So. 133 (1931) ; McIntosh v. Hastings, 156 Mass. 344, 31 N.E. 288 (1892); Burke v. City of Kansas, 34 Mo. App. 570 (1889); Glacius v. Black, 50 N.Y. 145, 10 An. St. Rep. 449 (1872) ; J. Kennard \& Sons Carpet Co. v. Houston Hotel Ass'n, 197 S.W. 1139 (Tex. Civ. App. 1917); Smith v. Board of Educ., 76 W. Va. 239, 85 S.E. 513 (1915). Contra, Guthrie v. Carpenter, 162 Ind. 417, 70 N.E. 486 (1904) (change in construction authorized by the architect found binding on the owner).

This discussion does not cover the question of whether a surety can be discharged by a material change in the contract made by the architect. See Flall v. Union Indem. Co., 61 F.2d 85 (8th Cir. 1932) (dictum); Guthrie v. Carpenter, supra, holding in the affirmative. But see Columbia Security Co. v. Aetna Acc. \& Liab. Co., 108 Wash. 116, 183 Pac. 137 (1919), holding an unauthorized change did not discharge the surety.

11 See discussion of extras, text at notes 36-144 infra.

12 Thomas v. Stewart, 132 N.Y. 580,30 N.E. 577 (1892). There were some aspects of apparent authority, as the court mentioned that the owner had stated that everything was being left to the architect. Id. at 583, 30 N.E. at 579; Johnson v. Griffiths \& Co., 135 S.W. 683 (Tex. Civ. App. 1911) (court noted brands were of equal quality); Birdsall v. Perry Glass Works, 181 Iowa 1268, 161 N.W. 304 (1917). This court relied on the doctrines of substantial performance, inpossibility of performance, and waiver, to reach its result. The doctrine of substantial performance was rejected in a case where substituted material was inferior. Williams v. Board of Directors, 100 Ark. 166, 139 S.W. 1136 (1911). 
same issue have held no such authority existed. ${ }^{13}$ The apparently contradictory holdings can be resolved by a consideration of the nature of the variance accepted or ordered by the architect. The greater the variance, the less likely the court will find authority in the architect. A more orderly analysis would be effected if the courts considered the ordering or accepting of the work by the architect as evidence tending to prove substantial performance, rather than regarding his act as the operative fact upon which liability turned. Such an analysis would avoid the indiscriminate use of language dealing with scope of authority in cases where the issues are distinctly different.

A modified contract may give rise to the question whether the owner has cause to discharge the contractor and replace him on the job. In $R$. Lee Tolley Co.v. Marr, ${ }^{14}$ the owner had ordered the contractor off the job on the grounds that he had deviated from the contract. The contractor sued for breach of contract, claiming the work was done on orders from the architect and the deviations were made necessary by the architect's errors. A sympathetic court agreed with the contractor. The court recognized that the architect could not change the contract, but held that the contractor should not suffer because the owner had hired an incompetent architect. ${ }^{15}$ Certainly if the contractor can sue the owner for damages caused by the errors of the architect, a point which will be developed in detail later, ${ }^{16}$ he ought to be able to use these errors as an excuse for his non-performance. Authority to modify should not be considered as the issue in this situation.

Authority to modify, usually called waiver by the courts, may arise in another context. As a rule, construction contracts require that certain notices be given in writing by the contractor and that certain orders by the architect be in writing. Also, the contract may require the contractor to furnish proof that he has paid his subcontractors and materialmen. These

13 Davies v. Kahn, 251 F.2d 324 (4th Cir. 1958) (cannot require brand not called for by contract); Williams v. Board of Directors, supra note 12 (cannot allow rubble masonry where contract called for concrete culverts); Cannon v. Hunt, 113 Ga. 501, 38 S.E. 983 (1901); Glacius v. Black, 50 N.Y. 145, 10 Am. St. Rep. 449 (1872) ; People v. Lewis, 159 App. Div. 612, 145 N.Y. Supp. 862 (4th Dep't 1913) (cannot accept concrete foundation for stone and brick); J. Kennard \& Sons Carpet Co. v. Houston Hotel Ass'n, 197 S.W. 1139 (Tex. Civ. App. 1917) (cannot order fixtures other than those called for in contract).

1412 Tenn. App. 505 (1931) (AIA Standard Contract).

15 "We know of no rule of law which would hold the contractor responsible for errors made by the architect or for decisions and defective plans which render it impossible to construct the building according to specifications. If the owner selects a negligent and inefficient architect, he has no grounds to complain because the contractor cannot construct the building according to the plans and has to deviate from them, upon order of the architect in order to correct the mistakes of the architect. As long as the contractor gains no undue advantage, because of the architect's mistakes, then he is not responsible to the owner for the confusion and alteration made necessary because of the gross mistakes of the architect." Id. at 512 .

${ }^{16}$ See discussion, text at notes 145-53 infra. 
provisions are inserted to protect the owner. With the exception of an occasional dictum, ${ }^{17}$ the courts have held firmly that the architect cannot eliminate these requirements. ${ }^{18}$

A number of cases go into the question of incidental authority. ${ }^{10}$ Does giving the architect authority to perform a certain act mean he has authority to perform acts necessary to do the primary act or acts closely related to it? The fact situations which have presented these questions are so diverse that no useful function would be served by lengthy analysis..$^{20} \mathrm{Custom}$, usage and common sense are the best guides in this area.

The preceding discussion has assumed that the sole source of the architect's power to affect the owner has stemmed from the owner-contractor contract. The result may be different when subsequent acts of the owner are relied on. In such a case, the contractor may claim the owner is estopped

17 Wacker v. Essex, 67 Ind. App. 584, 119 N.E. 466 (1918) (that request for extensions be in writing). Contra, Wm. P. Jungclaus Co. v. Ratti, 67 Ind. App. 84, 118 N.E. 966 (1918).

18 The architect cannot waive the requirement that changes, whether or not they are extras, be ordered in writing. Volquardsen v. Davenport Hosp., 161 Iowa 706, 141 N.W. 432 (1913); L'Hommedieu v. Winthrop, 59 App. Div. 192, 69 N.Y. Supp. 381 (2d Dep't 1901); Hurley v. Kiona-Benton School Dist., 124 Wash. 537, 215 Pac. 21 (1.923). He cannot allow a contractor to submit estimates when the contract requires monthly invoices. Hall v. Union Indem. Co., 61 F.2d 85 (8th Cir. 1932). Nor can he waive a requirement that the contractor submit a certificate that inaterials have been paid for. Leverone v. Arancio, 179 Mass. 439, 61 N.E. 45 (1901). The architect cannot waive the requirement that extensions of time be requested in writing. Wm. P. Jungclaus Co. v. Ratti, supra note 17; Kelly v. Fejervary, 111 Iowa 693, 83 N.W. 791 (1900) ; Davis v. La Crosse Hosp. Ass'n, 121 Wis. 579, 99 N.W. 351 (1904); J. C. Wagner Co. v. Cawker, 112 Wis. 532, 88 N.W. 599 (1902) (citing many cases). See also Vanderhoof v. Shell, 42 Ore. 578, 72 Pac. 126 (1903), where the court talked about waiver by the architect but relied on the fact that the contract did not require written notice.

19 Restatement (Second), Agency \$ 35 (1958).

20 Giving an architect authority to obtam bids does not give him authority to enter into a contract, especially where the owner had already rejected two bids sent in by the architect. Albert Steinfeld \& Co. v. Broxholme, 59 Cal. App. 623, 211 Pac. 473 (1922). Accord, Harrigan \& Reid Co. v. Hudson, 291 Mich. 478, 289 N.W. 222 (1939). But telling the contractor to "negotiate" with the architect gave the architect authority to inodify a proposed contract. Sando v. Kalberg, 138 Wash. 247, 244 Pac. 576 (1926). See discussion of this case, text at note 4 supra. Indiana, whose decisions in this field are often at variance with those of other States, has held that a superintendent authorized by statute to let contracts has authority to require work beyond the contract. Board of Comm'rs v. Byrne, 67 Ind. 21 (1879). Authority to see that claims were paid and that no liens existed did not give authority to pay clains, Lewis v. Slack, 27 Mo. App. 119 (1887), and giving the architect authority to pay money to the contractor's order does not give the architect authority to enter into a contract, Dodge v. McDonnell, 14 Wis. 600 (1861). Authority to condeunn defective work and material did not give authority to require iron beams larger than called for by the contract. Columbia Security Co. v. Aetna Acc. and Liab. Co., 108 Wash. 116, 183 Pac. 137 (1919). Similar authority in Drum. mond v. Hughes, 91 N.J.L. 563, 104 Atl. 137, (Ct. Err. \& App. 1918), was held to authorize the architect to approve a particular brand of material when the contract called for an "approved" brand. Authority to fire "undesirable" workers did not anthorize the architect to send nonumion inen off the job when another contractor complained. E. C. Gerhard Bldg. Co. v. City of Dallas, 298 Fed. 264 (5th Cir. 1924). 
from denying the architect's authority, that the owner has ratified the architect's unauthorized act, or that apparent authority in the architect has been created by the owner. Cases using these doctrines as a rule turn on unusual facts, ${ }^{21}$ but one situation occurs with sufficient frequency to merit mentioning at this point.

An owner often goes out on the job to see how the work is coming. In his presence, the architect may direct that certain work be done, a direction which may be beyond his authority under the owner-contractor agreement. The courts have held that the contractor must check with the owner if the latter is present.22 The contractor cannot assume that the owner's presence means the latter has impliedly assented to increasing the architect's authority. The mere fact of his presence should not by itself enlarge the architect's authority. ${ }^{23}$

\section{Authority to Receive Mechanics' Lien Notices and Notices of Assignments}

Mechanics' Lien laws often require that a notice of lien be served upon the owner or his agent by the lien claimant. The contractor may serve the architect and the question is whether such service complies with the statute. In deciding this, the courts must face the question of scope of authority. The cases have held that the architect, unless his authority extends to paying out money, has no authority to receive lien notices even if he makes out

21 Whether the owner would be bound by an order for extra work issued by the superintendent was a jury question where the owner told contractor he would not be around much and orders from the superintendent would be the same as if they came from him. Merrill v. Worthington, 155 Ala. 281, 46 So. 477 (1908). Where the owners told the contractor that they depended upon the architect and they would endorse his instructions, the court held the jury properly rejected apparent authority since this could show, along with other evidence, that the endorsement covered only those acts authorized under the contract. Enployers Liab. Assur. Corp. v. Sheftall, 97 Ga. App. 398, 103 S.E.2d 143 (1958) (AIA Standard Contract). Ratifying 17 changes in the plans by the architect was held to create apparent authority to make a change calling for payment beyond the contract price. Jackson Architectural Iron Works v. Rouss, 39 N.Y. St. Rep. 359, 15 N.Y. Supp. 137 (N.Y. City Super. Ct. 1891), aff'd without opinion, 133 N.Y. 538, 30 N.E. 1148 (1892). A ratification was found where the owner did not object to the architect's purchase after being told about it and before goods were shipped. Crockett v. Chattahoochee Brick Co, $95 \mathrm{Ga} .540,21$ S.E. 42 (1894). Estoppel is often mentioned but rarely held to exist. See, e.g., Brown v. Coffee, 17 Cal. App. 381, 121 Pac. 309 (1911) (owner did not know of change) ; Reifsnyder v. Dougherty, 301 Pa. 328, 152 Atl. 98 (1930) (owner not estopped by failing to take steps to check on whether agent was giving unauthorized orders). It is sometimes the basis of an alternative holding. Davies v. Kahn, 25I F.2d 324 (4th Cir. 1958); Jackson Architectural Iron-Works v. Rouss, supra; Stewart v. Pennsylvania State Camp, 122 Pa. Super. 30, 184 Atl. 476 (1936).

22 Brown v. Coffee, 17 Cal. App. 381, 121 Pac. 309 (1911); Starkweather v. Goodman, 48 Conn. 101 (1880); Campbell v. Day, 90 III. 363 (1878); cf. R. Lee Tolley Co. v. Marr, 12 Tenn. App. 505 (1931).

${ }^{23}$ See discussion of effect of owner's presence in "extras" cases, text at note 92 infra. 
estimates and certificates upon which payments are made. ${ }^{24} \mathrm{~A}$ few States have modified this rule by statute. ${ }^{25}$ Also, if an assignee gives notice of his assignment to the architect, this notice does not protect the assignee if the owner, without knowledge of the assignment, pays the assignor. ${ }^{26}$

\section{Admissibility of Extra-Judicial Statements Made by the Architect}

Another problem pertaining to the scope of the architect's authority is the extent to which statements made out of court by the architect are admissible against the owner. ${ }^{27}$ Whether the statements are received as exceptions to the hearsay rule depends upon whether the statements are within the scope of the agent's authority. ${ }^{28}$

Before discussing scope of authority, two situations should be discussed which appear to involve the hearsay rule but do not. Proffered testimony may be inadmissible because, in light of the substantive law, the statement is immaterial. ${ }^{29}$ The statement, if made, would not affect the case. For example, if the architect has no authority to bind the owner in contract, any statement by the architect in or out of court that the owner would pay for the work is inadmissible in an action by the contractor against the owner since it is immaterial. ${ }^{30}$ Even if true, it has no bearing on the lawsuit against the owner.

24 Norfolk Bldg. Supplies Corp. v. Elizabeth City Hosp., 176 N.C. 87, 97 S.E. 146 (1918) (dictum, since court found notice itself did not comply with statute); Drummond v. Rice, 27 Pa. Super. 226 (1904); Langenheim v. Anschutz-Bradberry Co., 2 Pa. Super. 285 (1896); Burns \& Hamilton Co. v. Denver Inv. Co., 217 S.W. 719 (Tex. Civ. App. 1919); Ellis-Mylroie Lumber Co. v. St. Luke's Hosp., 119 Wasl. 142, 205 Pac. 398 (1922) (by implication) ; Bates Expanded Steel Truss Co. v. Sisters of Mercy, 208 Wis. 457, 243 N.W. 456 (1932). Note that Pennsylvania by statute has changed the result. See note 25 infra.

25 Colo. Rev. Stat. ANn. \$ 86-3-2(A) (1953); Irr. Rev. Stat. ch. 82, 824 (1957); Pa. Stat. Ann. tit. 49, § 101 (Purdon Supp. 1957). See also Pa. Stat. AnN. tit. 49, \& 23 (Purdon Supp. 1957), which deals with notices required to be served where repair work is done by subcontractors. See Keber v. Stellato, 77 Pa. D. \& C. 314 (C.P. 1952), holding notices under both sections in some cases are required.

26 Renton v. Monnier, 77 Cal. 449, 19 Pac. 820 (1888). Cf. Cbicago Lumber \& Coal Co. v. Garmer, 132 Iowa 282,109 N.W. 780 (1906), where the court beld that notice to architect that plaintiff was furnisling material was not notice to the owner. The owner had paid off the contractor who had not paid the plaintiff materialinan. The court noted that it was not within the scope of the arcliitect's authority to ascertain the source of the material.

27 At tines it is even contended that the architect is an agent of the contractor and that stateinents by bim are admissible against the contractor. Compare Congregation Ohab Shalom v. Hathaway, 216 Mass. 539, 104 N.E. 379 (1914), with J. L. Mott Iron Works v. Kaiser Co., 131 S.C. 394,103 S.E. 783 (1920).

283 WIGMORE, EVIDENCE § 1078 (3rd ed. 1940).

291 id. \& 2 (3rd ed. 1940).

30 Myers Constr. Co. v. Wood River Drainage \& Levee Dist., 221 Ill. App. 473 (1921) (dictum, since admitted on another theory); Iowa Elec. Light \& Power Co. v. Hopp, 221 Iowa 680, 266 N.W. 512 (1936) (AIA Standard Contract); Alexander v. Grenada Bank, 2 Tenn. App. 580 (1926). The courts in these cases talk about scope of autbority when the real issue is materiality. Cf. LaFayette Ry. v. Tucker, 124 Ala. 514, 27 So. 447 (1900), where the testimony was admitted since there was a jury question on the authority of the engineer to order that the work be done. 
The non-hearsay use has been a method by which the contractor has been able to get into evidence an out of court statement by the architect. ${ }^{31}$ In one case the architect's statement that the owner would pay for the work was admitted to show that the contractor had given notice that he was being delayed due to the fault of the owner. It was admitted not to prove the truth of the matter stated but that the statement was made. ${ }^{32}$

In the true hearsay cases, statements made by the architect respecting his duties under the contract are admissible. Since he is generally judge of performance and workmanship, statements as to these matters, if all the requirements for an admission are present, are admissible, ${ }^{33}$ as well as statements that the building has been constructed in accordance with the plans and specifications. ${ }^{34}$ As an example, where he had the duty to make certificates as to the amount of work included in the completed contract, a statement by an engineer that he considered certain work and had not included it was admissible to show the work in question was extra. ${ }^{35}$

\section{Authority to Order Extra Work and to Excuse the Condition Precedent of a Written Order for the Extra Work}

One of the most troublesome areas of the owner-architect-contractor relationship deals with extras. Frequently, the owner or architect determines that certain work not called for by the contract must be done. When the contractor submits his bid, it is based upon the original plans and specifications, and if he is ordered to do and does extra work he is entitled to additional compensation.

Building contracts customarily contain a clause which provides that no claim will be allowed for extra work unless it is ordered in writing by the owner, the architect, or both. ${ }^{36}$ The American Institute of Architects Standard Contract also provides that if the contractor receives an instruction, by drawing or otherwise, which he believes will be extra work, he must give the architect written notice within a reasonable time after receipt of the instruction or before the work is done if he is to collect for it. ${ }^{37}$ There is an

316 WTGMORE, EvIDENCE $§ 1766$ (3d ed. 1940).

32 Myers Constr. Co. v. Wood River Drainage \& Levee Dist., 221 Ill. App. 473 (1921); cf. Crainp \& Co. v. Boyertown Burial Casket Co., 241 Pa. 15, 88 Atl. 69 (1913). (1892).

33 Hudspeth v. Allen, 26 Ind. 165 (1866); Wright v. Reusens, 133 N.X. 298, 31 N.E. 215

34 Fleming v. Lunsford, $163 \mathrm{Ala} .540,50$ So. 921 (1909). But a conversation between the witness and the architect which led to the issuance of a payment certificate was not admitted, even though the issuance of the certificate was clearly within the scope of the architect's authority. Mallard, Stacy \& Co. v. Moody, 105 Ga. 400, 31 S.E. 45 (1898).

35 Douglass \& Varnum v. Village of Morrisville, 89 Vt. 393, 95 Atl. 810 (1915).

30 AIA Standard Contract, art. 15.

37 Id., art. 16. 
exception for work which is necessary in emergency situations endangering life or property. ${ }^{38}$

The writing requirement has spawned a staggering amount of litigation..$^{30}$ Much of this litigation resulted from inadequately drafted provisions, but even the well-drafted AIA Standard Contract has found its way into the courts.

The writing requirement has four purposes:

(1) To keep the owner informed as to his costs.

(2) To protect the owner from having to pay for work he does not want.

(3) To insure that the work has been ordered.

(4) To constitute evidence that the work is, in fact, extra..$^{40}$

The main purpose of this private Statute of Frauds is to avoid litigating the difficult questions of whether the work was ordered and, even more important, was the work in fact extra. ${ }^{41}$ Many cases involve a conflict of testimony between the contractor and the architect or the owner as to whether the work was ordered..$^{2}$ Alnost every case is enmeshed in the difficult fact question of whether the work is extra. Often the architect refuses to issue a written order because he believes the work to be within the contract. ${ }^{43}$ Many extra claims are asserted long after the work is performed, and even

38 Ibid.

39 "Disputes between contractors and owners as to extra work and changes on building or working contracts are as old as the practice of contracting for such work, and are a fertile cause of litigation." Headley v. Cavileer, 82 N.J.L. 635, 637, 82 Atl. 908, 909 (Sup. Ct. 1912). See also James Reilly Repair \& Supply Co. v. Smith, 177 Fed. 168, 169 (2d Cir. 1910), where the court characterized extra claims as "apparently inevitable and always exasperating."

40 See also Hudson, BuIIding Contracts 309 (6th ed. 1933); Note, 31 Irx. L. REv. 780, 784 (1937), where the need for preventing fraudulent claims was recognized, but the difficulty of proof as to whether the work was in fact an extra was seemingly ignored. See Carter v. Root, 84 Neb. 723, 121 N.W. 952 (1909). This Article will not deal with whether the work is in fact an extra. Such questions depend on the wording of the contract and the facts of each case.

41 The owner may place a ceiling on his costs. If the architect can order in writing, the use of the cost-ceiling clause to enable the owner to avoid paying for work he does not want is diminished considerably.

42 See, e.g., Weber-Squires Corp. v. Firestone Tire \& Rubber Co., 76 F.2d 711 (5th Cir. 1935) ; Furton v. City of Menasha, 71 F. Supp. 568 (E.D. Wis, 1947); O'Keefe v. St. Francis Church, 59 Conn. 551, 22 Atl. 325 (1890) ; Iowa Elec. Light \& Power Co. v. Hopp, 221 Iowa 680, 266 N.W. 512 (1936) (AIA Standard Contract) ; Chicago Lumber \& Coal Co. v. Garmer, 132 Iowa 282, 109 N.W. 780 (1906) ; Rens v. City of Grand Rapids, 73 Mich. 237, 41 N.W. 263 (1889) ; Ashley v. Henahan, 56 Ohio St. 559, 47 N.E. 573 (1897); Gibbs v. School Dist., 195 Pa. 396, 46 Atl. 91 (1900); Bannon v. Jackson, 121 Tenn. 381, 117 S.W. 504 (1908) ; Essex v. Murray, 29 Tex. Civ. App. 368, 68 S.W. 736 (1902).

43 Rivercliff v. Linebarger, 223 Ark. 105, 264 S.W.2d 842 (1954), cert. denied, 348 U.S. 834 (1954); O'Leary v. Board of Port Comm'rs, 150 La. 649, 91 So. 139 (1922); Schneider v. City of Ann Arbor, 195 Mich. 599, 162 N.W. 110 (1917); Ashley v. Henahan, supra note 42. This aspect of Rivercliff v. Linebarger, supra, had an unusual result. See text at note 83 infra. 
long after the contract is completed. ${ }^{44}$ The courts have recognized a propensity of some contractors to bid too low and try to bail their way out of a losing contract by claiming extras. ${ }^{45}$ Occasionally the courts have recognized the possibility of collusion between the contractor and the architect, when the owner has no technical knowledge and must rely on the architect. ${ }^{4 b}$ Contractors, as a rule, are not unsophisticated businessmen, and these clauses are almost always used and do not constitute traps for the unwary.

On the other hand, the owner should not receive benefits without paying for them. Contractors may have to deal with an arbitrary architect ${ }^{47}$ or with an architect who promises a writing and does not execute the written order at the promised time. ${ }^{48}$ One method used by the courts to avoid what appears to them to be an unjust result is to construe the contract narrowly to find that there was no requirement that a written order be issued prior to commencing work $\mathrm{k}^{49}$ or that extra material did not come within a provision

44 Carter v. Root, 84 Neb. 723, 121 N.W. 952 (1909) ; Lundstrom Constr. Co. v. Dygert, 94 N.W.2d 527 (Minn. 1959) (5-6 months after final claim which did not list extras); Kansas City Bridge Co. v. State, 61 S.D. 580, 250 N.W. 343 (1933) (court noted extras not included in monthly estimates); Bannon v. Jackson, 121 Tenn. 381, 117 S.W. 504 (1908) (claim presented 6 months after completion); Wenzeler \& Ward Plumbing \& Heating Co. v. Sellen, 330 P.2d 1068 (Wash. 1958) (claim not submitted until long after completion of contract); Ericksen v. Edmonds School Dist., 13 Wash. 2d 398, 125 P.2d 275 (1942).

45 Jefferson Hotel Co. v. Brumbaugh, 168 Fed. 867, 875 (4th Cir. 1909), where the court stated: "The temptation on the part of contractors to recoup losses on improvident contracts by claims of this kind [extra work] is frequently present and strong. It is therefore the clear duty of the courts to carefully scrutinize such demands and allow them only upon clear and satisfactory evidence sustaining them." See also Furton v. City of Menasha, 71 F. Supp. 568 (E.D. Wis. 1947).

46 McGratty v. Haberman, 127 App. Div. 199, 111 N.Y.Supp. 48 (2d Dep't 1908), af'd. mem., 197 N.Y. 511, 90 N.E. 1161 (1909); Bannon v. Jackson, 121 Tenn. 381, 117 S.W. 504 (1908).

47First Sav. \& Trust Co. v. Milwaukee County, 158 Wis. 207, 148 N.W. 22 (1914). The court stated the evidence tended to show: "[T]he engineer gave peremptory orders which he refused to put in writing ... and [said] that he would drive the contractor off the work if they were not obeyed ...."Id. at 230, 148 N.W. at 30 .

48 Atlewed v. City of Marysville, 295 Mich. 102, 294 N.W. 110 (1940) (no recovery against city, however).

49 S. J. Groves \& Sons Co. v. Turnpike Comm'n, 164 F. Supp. 816 (S.D. W. Va. 1958). A typical example is seen in M. DeMatteo Constr. Co. v. Commonwealth, 156 N.E.2d 659 (Mass. 1959). Here a bridge collapsed on May 22, 1952, and an emergency resulted. The plaintiff contractor was told, after a number of conferences, to rebuild starting in the middle of June 1952. The chief engineer told the contractor to be ready to work nights, Sundays and hohdays, to keep strict account of the costs, and "they would nnake out the necessary extra work order." 156 N.E.2d at 667 . On May 18, 1953, the contractor was told no more work would be needed. On June 16, 1953, he submitted his claim for extra work. The State issued a written extra order on Dec. 21, 1953, which was approved by the district highway engineer on Jan. 5, 1954. State officials changed their minds on May 11, 1954, and reversed this charge on June 15, 1954, agreeing to pay some $\$ 137,000$ when the claim was for around $\$ 195,000$.

The contract provided that the contractor would be required to do extra work if ordered in writing. It also provided that no claims for extras ordered orally would be allowed unless 
covering extra work. ${ }^{50}$ Another technique used is to hold that no writing requirement remains if the contract has been abandoned.51 Also, the extra work ordered may be so far beyond the contemplation of the parties that the work does not come under the extras provision of the contract. ${ }^{62}$ To illustrate, work which is ordered may fall into three categories: (1) It may be required under the contract and not be an extra; (2) it may not be required under the contract, but be sufficiently related to the subject matter of the basic contract to be governed by the extras provision; (3) it may be so unrelated in subject inatter to the basic contract or be so extensive in scope that it is not controlled by the extras provision. This last category rarely occurs and is only used by the courts to achieve a result. Implicit in much of the language of the courts is a distrust for provisions which they feel are merely technical. ${ }^{53}$

contractor filed a written notice within a week from beginning the work, and that in the absence of such a notice, which required an itemized statement, his claim would be forfeited and invalid. To avoid an unjust result in a case which exhibited inexcusable conduct on the part of the State, the court construed the contract as not requiring a written order before commencement of the work, and thus if a written order was eventually given, no statement of intention to do the work was needed. The court also stressed the emergency situation and the impracticality of any alternative course.

50 Interstate Lumber Co. v. Western Mortgage \& Warranty Title Co., 51 Mont. 190, 149 Pac. 975 (1915).

$51 C f$. Hayden v. City of Astoria, 74 Ore. 525, 145 Pac. 1072 (1915). Here the court held excessive use of the engineer's authority to make changes constituted an "abandonment." Therefore, the contract unit price and no-damage clause did not apply, and the contractor was allowed to recover in quantum meruit. There was no writing requirement, but, by analogy, if the contract were abandoned there would be no writing requirement. It could be contcnded that there was authority to order orally while if there were a written order requirement, oral orders would not be a basis for even a quantum meruit action. But if the court felt the work was done, it might use another rationale such as acceptance and retention of benefit or errors of the engineer, to surmount that hurdle. See text at note 78 infra.

In the Hayden case, the court ignored the difficult problem of whether a municipality can be held to an implied contract, especially where there is no appropriation. See, e.g., City and County of San Francisco v. Transbay Constr. Co., 134 F.2d 468 (9th Cir. 1943), cert. denied, 320 U.S. 749 (1943) ; H. J. McNeel, Inc. v. Canyon County, 76 Idaho 74, 277 P.2d 554 (1954); Bancroft v. Millcreek Township, $335 \mathrm{~Pa} .529,6$ A.2d 916 (1939); Town of Worland v. Odell \& Johnson, 329 P.2d 797 (Wyo. 1958) (citing many authorities); Annot., 154 A.L.R. 356 (1945).

Hayden v. City of Astoria, supra, has rarely been followed in Oregon. Either the court distinguishes it, Friberg v. Elrod, 136 Ore. 186, 296 Pac. 1061 (1931) (could not bring quantum meruit action under mechanics' lien law), or holds no abandonment, Feldschau v. Clatsop County, 117 Ore. 482, 244 Pac. 528 (1926); Multnomah County v. Standard Ain. Dredging Co., 92 Ore. 261, 180 Pac. 508 (1919).

\$2 Salt Lake City v. Smith, 104 Fed. 457 (8th Cir. 1900); Mulholland v. Mayor of New York, 113 N.Y. 631, 20 N.E. 856 (1889).

53 Jefferson Hotel Co. v. Brumbaugh, 168 Fed. 867 (4th Cir. 1909), where the court states: "Under such circumstances it has become immaterial whether the technical requirements of the contract as to these extras being ordered in writing was strictly carried out or not, because it must be held to have been waived." Id. at 867 . See also Chicago \& E.I.R.R. v. Moran, 187 Ill. 316, 58 N.E. 335 (1900) (technicality of no notice in writing); Lundstrom Constr. Co. v. Dygert, 94 N.W.2d 527 (Minn. 1959) (detail of performance, not of essence) ; Walberg v. Jacobson, 143 Minn. 210, 173 N.W. 409 (1919) (detail of perfornance, not of the essence). 
Prior to analyzing the writing requirement, there must be an order for the extras ${ }^{54}$ by the owner or someone who has authority to order extras, whether orally or in writing. As pointed out earlier, the architect ${ }^{55}$ has no inherent authority to contract on behalf of the owner or to modify an existing contract. ${ }^{56}$ Therefore, where he has no specific authority, or where the contract requires the authorization of the architect and someone else, the courts have not held the owner, ${ }^{5 \tau}$ in the absence of conduct of the owner which would create apparent authority, constitute a waiver or estop the owner from raising the writing requirement as a defense. ${ }^{58}$

Where the owner-contractor agreement authorizes the architect to order extras but limits this authority by requiring that the order be in writing, ${ }^{59}$ an oral order by the architect or comparable official will not bind the owner.$^{00}$ The courts have so held in cases where the contractor has been able

54 Gillison v. Wannamaker, $140 \mathrm{~Pa} .358,21$ Atl. 361 (1891), where there was only an acceptance by the architect of the extra work at the completion of the contract, and no order.

55 Where architect is referred to in this section, the statement also applies to engineers.

56 See text at notes 7, 10 supra.

67 Weber-Squires Corp. v. Firestone Tire \& Rubber Co., 76 F.2d 711 (5th Cir. 1935); United States v. Walsh, 115 Fed. 697 (2d Cir. 1902) (contract required order by commission); Gray v. La Societé Française de Bienfaisance Mutuelle, 131 Cal. 566, 63 Pac. 848 (1901) (contract required order of architect and building committee); Contra Costa Constr. Co. v. Daly City, 48 Cal. App. 622, 192 Pac. 178 (1920) (contract required order from board of trustees); J. M. Griffith Co. v. City of Los Angeles, 54 Pac. 383 (Cal. 1898) ; Starkweather v. Goodman, 48 Conn. 101 (1880) ; Heard v. Dooly County, 101 Ga. 619, 28 S.E. 986 (1897) (contract required approval by ordinary); McIntosh v. Hastings, 156 Mass. 344, 31 N.E. 288 (1892); Schneider v. City of Ann Arbor, 195 Mich. 599, 162 N.W. 110 (1917); Rens v. City of Grand Rapids, 73 Mich. 237, 41 N.W. 263 (1889) (alternative holding). But see Teakle v. Moore, 131 Mich. 427, 91 N.W. 636 (1902) (contract designated architect as agent without any limitation of authority); Board of Supervisors v. Patrick, 54 Miss. 240 (1876) ; Kelly v. St. Michael's Roman Catholic Church, 148 App. Div. 767, 133 N.Y. Supp. 328 (2d Dep't 1912) ; People v. Snedeker, 106 App. Div. 89, 94 N.Y. Supp. 319 (2d Dep't), aff'd mem., 182 N.Y. 558, 75 N.E. 1133 (1905) (contract required authorization of town board); State Higlwway Comm'n v. Green-Boots Constr. Co., 199 Okla. 477, 187 P.2d 209 (1947) (contract required order by commissioner) ; Bancroft v. Millcreek Township, 335 Pa. 529, 6 A.2d 916 (1939); Day v. Pickens County, 53 S.C. 46, 30 S.E. 681 (1897); Ambaum v. State, 80 Wash. 122, 141 Pac. 314 (1914) (contract required approval of commissioner). Contra, Gibson County v. Motherwell Iron \& Steel Co., 123 Ind. 364, 24 N.E. 115 (1890); Board of Comm'rs v. Hill, 122 Ind. 215, 23 N.E. 779 (1889). Counsel for the plaintiff contractor in McIntosh v. Hastings, supra, requested an instruction that the architect had authority to order extra work on small matters as they occurred, but it was not given.

58 See note 21 supra, for cases involving apparent authority, estoppel and ratification.

50 Sometimes the problem is what is a sufficient writing. See Sartoris v. Utah Constr. Co., 21 F.2d 1 (9tlı Cir. 1927); Crane Constr. Co. v. Coinmonwealth, 290 Mass. 249, 195 N.E. 110 (1935) ; Stuart v. City of Cambridge, 125 Mass. 102 (1878) ; Note, 31 ILL. L. REv. 780, 783-84 (1937); Annot., 66 A.L.R. 659 (1930).

60 Massachusetts Bonding \& Ins. Co. v. Lentz, 40 Ariz. 46, 9 P.2d 408 (1932) (AIA contract); White v. San Rafael \& San Quentin R.R., 50 Cal. 417 (1875); Iowa Elec. Light \& Power Co. v. Hopp, 221 Iowa 680, 266 N.W. 512 (1936) (AIA contract); Des Moines Plumbing \& Heating Co. v. Margarian, 201 Iowa 647, 207 N.W. 750 (1926) (AIA contract); Benson \& Marxer v. Brown, 190 Iowa 848, 179 N.W. 81 (1920) (dictum); Chicago Lumber \& Coal Co. 
to make out a persuasive case on the equities. ${ }^{61}$ It has even been held that performance without a written order is a waiver of a claim for payment. ${ }^{62}$ Also, the owner will not be bound if the architect fails to demand written estimates relating to the extra work if such estimates are required by the contract. ${ }^{63}$ Even establishing custom and usage of the industry will not cure a failure to comply with the express terms of the contract. ${ }^{64}$

v. Garmer, 132 Iowa 282, 109 N.W. 780 (1906) ; Dolman v. Board of Comm'rs, 116 Kan. 201, 226 Pac. 240 (1924) ; O'Leary v. Board of Comm'rs, 150 La. 649, 91 So. 139 (1922) (sce LA. Star. ANN., Crvir Code, arts. 2763, 2764) ; Crane Constr. Co. v. Commonwealth, supra note 59; Burns v. Thorndyke, 228 Mass. 552, 117 N.E. 799 (1917) ; Stuart v. Cambridge, supra note 59; Hunt v. Owen Bldg. \& Inv. Co., 219 S.W. 138 (Mo. App. 1920) (AIA contract); Ahern v. Boyce, 19 Mo. App. 552 (1885) ; Carter v. Root, 84 Neb. 723, 121 N.W. 952 (1909); Van Buskirk v. Board of Educ., 78 N.J.L. 650, 75 Atl. 909 (Ct. Err. \& App. 1910) ; Langley v. Rouss, 185 N.Y. 201, 77 N.E. 1168 (1906) (leading case); Woodruff v. Rochester \& P.R.R., 108 N.Y. 39, 14 N.E. 832 (1888) ; Traitel Marble Co. v. Brown Bros., Inc., 159 App. Div. 485,144 N.Y. Supp. 562 (1st Dep't 1913) ; McGratty v. Haberman, 127 App. Div. 199, 111 N.Y. Supp. 48 (2d Dep't 1908), aff'd mem., 197 N.Y. 511, 90 N.E. 1161 (1909) ; Baltimore \& O.R.R. v. Jolly Bros. \& Co., 71 Ohio St. 92, 72 N.E. 888 (1904) ; Ashley v. Henahan, 56 Ohio St. 559, 47 N.E. 573 (1897) (alternative holding); Montgomery v. City of Philadelphia, $391 \mathrm{~Pa} .607,139$ A.2d 347 (1958) (by implication); Gibbs v. School Dist., 195 Pa. 396, 46 Atl. 91 (1900); Bannon v. Jackson, 121 Tenn. 381, 117 S.W. 504 (1908); Campbell Bldg. Co. v. State Road Comm'n, 95 Utah 242, 70 P.2d 857 (1937); Ambaum v. State, 80 Wash. 122, 141 Pac. 314 (1914) (dictum); Wiley v. Hart, 74 Wash. 142, 132 Pac. 1015 (1913). Some cases have held the owner on oral orders. One case spoke of inherent authority of a supervisor. Causte v. Board of Chosen Freeholders, 9 N.J. Misc. 2, 152 Atl. 640 (Ch. 1930) (action by subcontractor against contractor). Another employed equitable estoppel but based its holding on a new contract entered into by the engineer who appeared to have authority to do so. Chicago \& E.I.R.R. v. Moran, 187 III. 316, 58 N.E. 335 (1900). A third merely held that the lower court was incorrect in using a provision which required all supplemental agreements to be $m$ vriting to justify a finding of law that there could be no estoppel based upon acts of the engineer. Kenefick-Hoffman \& Co. v. Raleigh, C. \& S. Ry., 171 N.C. 139, 88 S.E. 151 (1916).

01 Where the architect and contractor agreed on the price for the extra work but did not draw up an order, the Massachusetts court held for the owner, relying upon steps that the contract required the contractor to take if given an oral order. Crane Constr. Co. v. Commonwealth, 290 Mass. 249, 195 N.E. 110 (1935). Where the architeet, who ordered the work orally was secretary-treasurer of the owner corporation, the contractor still lost. Traitel Marble Co. v. Brown Bros., Inc., supra note 60. But see Riverchiff v. Linebarger, 223 Ark. 105, 264 S.W.2d 842 (1954), cert. denied, 348 U.S. 834 (1954), where the owner lost, the court stressing that the architect was a part-owner as well as other facts. Even where the court finds for the owner, it may look at the equities on the contractor's side. Des Moines Plumbing and Heating Co. v. Margarian, supra note 60.

62 Dolman v. Board of Comm'rs, 116 Kan. 201, 226 Pac. 240 (1924) ; Campbell Bldg. Co. v. State Road Comm'n, 95 Utah 242, 70 P.2d 857 (1937). Contra, Sartoris v. Utah Constr. Co., 21 F.2d 1 (9th Cir. 1927), where the court found a failure to get a written agreement for new work was not a waiver. The work according to the court did not fall into the "extra" clause, but even if it did, a drawing satisfied the requirement. A provision that faijure on the part of the contractor to give notice of extra work was a waiver of compensation was used by the parties in Wenzeler \& Ward Plumbing \& Heating Co. v. Sellen, 330 P.2d 1068 (Wash. 1958).

63 Joliet Bridge \& Iron Co. v. East Side Levee \& Sanitary Dist., 210 IIl. App. 575 (1918); Langley v. Rouss, 185 N.X. 201, 77 N.E. 1168 (1906) ; Ashley v. Henahan, 56 Obio St. 559, 47 N.E. 573 (1897).

64 McGratty v. Haberinan, 127 App. Div. 199, 111 N.J.. Supp. 48 (2d Dep't 1908), aff'd mem., 197 N.X. 511, 90 N.E. 1161 (1909). But where the court found the contract ambiguous, 
Despite the formidable barrier imposed by the writing requirement, there have been a number of cases where the contractor has recovered for oral orders of the architect. Since the oral order itself is not enough, these cases have involved additional facts which gave the court a peg upon which to hang its holding for the contractor.

The cases are in hopeless confusion as to the theoretical basis for holding the owner ${ }^{65} \mathrm{~A}$ court may employ the doctrines of waiver, ${ }^{66}$ apparent authority, ${ }^{67}$ estoppel, ${ }^{68}$ ratification, ${ }^{69}$ abandonment, ${ }^{70}$ and even substantial performance. ${ }^{71}$ Therefore, it seems more practical to focus on the operative facts of the cases, with an attempt to identify factors stressed by the courts. In this regard, it will be obvious that many of these holdings are based upon a combination of factors. A prediction cannot be based, as a rule, upon one or even several precedents, since the facts are seldom identical. One must try to find in a given fact situation the number of factors present which the courts have considered, along with any peculiar or compelling equities on either side.

In holding for the contractor, where the extras were ordered orally by the architect, engineer, or someone other than the owner, the courts have stressed the following facts:

(1) Order given by someone with more authority than that usually possessed by an architect,

(a) Corporate officers, manager, or other employee of owner ${ }^{72}$ or

it held weight could be given to the practice that written orders were issued long after work completed where price could not be determined in advance. M. DeMatteo Constr. Co. v. Commonwealth, 156 N.E.2d 659 (Mass. 1959).

65 See Annot., 66 A.L.R. 665 (1930).

66 Douglass v. Varnum v. Village of Morrisville, 89 Vt. 393, 95 Atl. 810 (1915).

67 S. J. Groves \& Sons Co. v. Turnpike Comm'n, 164 F. Supp. 816 (S.D. W. Va. 1958) (dictum).

68 Jefferson Hotel Co. v. Brumbaugh, 168 Fed. 867 (4th Cir. 1909).

69 Abells v. City of Syracuse, 7 App. Div. 501, 40 N.Y. Supp. 233 (4th Dep't 1896).

70 O'Keefe v. St. Francis Cburch, 59 Conn. 551, 22 Atl. 325 (1890).

71 Bavin \& Burch Co. v. Bard, 81 Cal. App. 722, 255 Pac. 200 (1927).

72 The Sappho, 94 Fed. 545 (4th Cir. 1899) (president); Rivercliff v. Linebarger, 223 Ark. 105, 264 S.W.2d 842 (1954), cert. denied, 348 U.S. 834 (1954) (architect was part-owner); Sisters of Charity v. Burke, 22 Cal. App. 230, 124 Pac. 472 (1912) (member of Catholic order); Mahoney v. Hartford Inv. Corp., 82 Conn. 280, 73 Atl. 766 (1909) (general manager); McGowan v. Gate City Malt Co., 89 Neb. 10, 130 N.W. 965 (1911) (superintendent of prime contractor orally ordered work from subcontractor); O'Keefe v. St. Francis Church, 59 Conn. 551, 22 Atl. 325 (1890) (priest) ; Van Nice v. Christian Reformed Church, 59 N.D. 564, 231 N.W. 604 (1930) (AIA contract involving member of building committee); Salzner v. Jos. J. Snell Estate Corp., 81 Utah 111, 16 P.2d 923 (1932) (manager). Contra, Traitel Marble Co. v. Brown Bros., Inc., 159 App. Div. 485, 144 N.Y. Supp. 562 (1st Dep't 1913) (architect was corporate officer). It should be noted that in McGowan v. Gate City Malt Co., supra, the contract even provided oral orders given by employees on the job would not be binding on the owner. Yet the court found for the subcontractor even though there was no authority in the superintendent to order extras in writing. The result seems quite close to the "inherent authority" spoken of in Causte v. Board of Chosen Freeholders, 9 N.J. Misc. 2, 152 Atl. 640 (Cb. 1930); see note 60 supra. It is very doubtful that this case would be followed where the architect ordered the work. 


\section{(b) Relative of owner. ${ }^{73}$}

(2) Owner present when work ordered orally. ${ }^{74}$

(3) Owner's course of conduct in

(a) Disregarding contract requirements for writing, or being aware that the architect was doing $\mathrm{so}^{75}$ or

(b) Paying for previous extra work ordered orally. ${ }^{70}$

73 Walberg v. Jacobson, 143 Minn. 210, 173 N.W. 409 (1919) (brother and husband); Michaud v. McGregor, 61 Minn. 198, 63 N.W. 479 (1895) (son); McLeod v. Genius, 31 Neb. 1, 47 N.W. 473 (1890) (son) ; Keahon Bros. v. Blank, 161 Misc. 874, 292 N.Y. Supp. 257 (Rockland County Ct. 1936) (mother-in-law).

74 Wellman v. Smith, 114 La. 228, 38 So. 151 (1905); Douglas \& Varnum v. Village of Morrisville, 89 Vt. 393, 95 Atl. 810 (1915). Contra, James Reilly Repair \& Supply Co. v. Smith, 177 Fed. 168 (2d Cir. 1910); Benson \& Marxer v. Brown, 190 Iowa 848, 179 N.W. 81 (1920); cf. R. Lee Tolley Co. v. Marr, 12 Tenn. App. 505 (1931) (AIA contract; no estoppel where the owner was present since there was no showing he knew the work was extra). Any Louisiana case cited must be read with LA. Crv. CODE ANN. arts. 2763, 2764 (West 1952), which state: Art. 2763: "When an architect or other workman has undertaken the building of a house by the job, according to a plot [sic] agreed on between him and the owncr of the ground, he cannot claim an increase of the price agreed on, on the plea of the original plot [sic] having been changed and extended, unless he can prove that such changes have been made in compliance with the wishes of the owner." Art. 2764: "An exception is made to the above provision, in the case where the alteration or increase is so great, that it cannot be supposed to have been made without the knowledge of the owner, and also where the alteration or increase was necessary and has not been foreseen." The Louisiana cases have been collected in Comment, Building Contracts in Louisiana, 7 LA. I. REv. 564, 571 (1947).

75 Ross Eng'r Co. v. Pace, 153 F.2d 35 (4th Cir. 1946). "From the beginning of the contract work the parties ... ignored the provisions as to written orders and proceeded with the work with hittle or no regard for them." Id. at 49. Schmulbach v. Caldwell, 196 Fed. 16 (4th Cir. 1912), af'd on other grounds, 215 Fed. 70 (4th Cir. 1914) (neither party adhering strictly); Cavanagh v. Keplinger, 204 Cal. 19, 266 Pac. 287 (1928); Meyer v. Berlandi, 53 Minn. 59, 54 N.W. 937 (1893) (proceeded throughout without reference to writing provision); Campbell v. Kimball, 87 Neb. 309, 127 N.W. 142 (1910) ; Walter v. Horwitz, 60 N.Y.S.2d 327 (Sup. Ct. 1946) ; Black v. Philip Miller Co., 169 Wash. 409, 14 P.2d 11 (1932) (disregarded throughout progress of work).

In Campbell v. Kimball, supra, the court stated: "Had these provisions [relating to written orders] ... been observed by the parties to it during the progress of the work, it is clear enough that anuch expense might have been avoided, and this suit never heard of, but the evidence from beginning to the end shows, beyond all question, that they were wholly and entirely ignored by the architects and all parties to the contract. If changes or the supply of extras were desired by defendants, they ordered them verbally and the changes and extras were made and supplied. So also with the architects. We have not found that a single order for changes or extras was made in writing, nor in many instances was anything said as to their cost. The provisions above referred to unight as well not have been incorporated into the contract." Id. at 314-15, 127 N.W. at 144. In Wenzeler \& Ward Plumbing \& Heating Co. v. Sellen, 330 P.2d 1068 (Wash. 1958), the lower court had found "abandonment" of the requirement, but the appellate court said there was no evidence of this and held for the owner. In McGowan v. Gate City Malt Co. 89 Neb. 10, 130 N.W. 965 (1911), there was a course of conduct of ignoring the requirement by a superintendent in charge of the job for the prime contractor. The court found for the subcontractor on the theory that the superintendent's course of conduct bound the prime contractor.

${ }^{76}$ Ross Eng'r Co. v. Pace, supra note 75; Riverchiff v. Iinebarger, 223 Ark. 105, 264 S.W.2d 842, cert. denied, 348 U.S. 834 (1954) (only one written order where several changes ordered); Hannan, Hickey Bros. Constr. Co. v. Chicago, B. \& Q. R.R., 247 S.W. 436 (St. Louis Ct. App. 
(4) Owner having paid for part of the work ordered orally.77

(5) Owner accepting and retaining benefits of extra work. ${ }^{78}$

(6) Situations requiring speedy action consisting of

(a) An emergency, ${ }^{79}$ or

(b) Objections to work made by building inspector. ${ }^{80}$

1923) (innumerable bills paid); Causte v. Board of Chosen Freeholders, 9 N.J. Misc. 2, 152 Atl. 640 (Ch. 1930) (payments in early stage of contract); National Bank of Commerce v. City of Watervliet, 97 Misc. 121, 160 N.Y. Supp. 1072 (Sup. Ct. 1916), aff'd mem., 178 App. Div. 944, 164 N.Y. Supp. 1103 (3d Dep't 1917) (payment on monthly estimates from time to time); McGrath Constr. Co. v. Waupaca-Green Bay Ry., 148 Wis. 372, 134 N.W. 824 (1912) (monthly payments for 8 months with orally ordered extras included). However, in Starkweather v. Goodman, 48 Conn. 101 (1880), the court rejected a similar contention on the theory that the work for which the first payment had been made by them had been wrought into the building and was beyond withdrawal. Rejecting an argument that the owner had a duty to notify the contractor of the architect's acting beyond his authority, the court held that there was no showing that the contractor suggested that there might be other orders by the architect. This distinction seems contrary to the norm of the "reasonable man," and the court would have been on firmer ground had it based its holding upon an insufficient showing of a course of conduct which could have been relied upon. In Walsh v. Howard \& Childs, 61 Misc. 328, 113 N.Y. Supp. 499 (Sup. Ct. 1908), it is stated by way of dictum that each instance of payment is a separate transaction, and previous payments without written orders cannot operate to ehminate the requirement of a writing. Accord, O'Keefe v. St. Francis Church, 55 Conn. 551, 22 Atl. 325 (1890).

Often the opinion does not specify whether the failure to abide by the requirement was payment on oral orders, merely ordering the work orally or being aware that the architect was doing so. Cases which specifically mention payment are found in this note. It is possible that, in the cases cited in note 75 supra, there was payment, but the court does not mention it.

77 Abells v. City of Syracuse, 7 App. Div. 501, 40 N.Y. Supp. 233 (4th Dep't 1896).

78 Sartoris v. Utah Constr. Co., 21 F.2d 1 (9th Cir. 1927); Schmulbach v. Caldwell, 196 Fed. 16 (4th Cir. 1912); Jefferson Hotel Co. v. Brumbaugh, 168 Fed. 867, 875 (4th Cir. 1909); Bavin \& Burch Co. v. Bard, 81 Cal. App. 722, 255 Pac. 200 (1927); Chicago \& E..I.R.R. v. Moran, 187 Il. 316, 58 N.E. 335 (1900); W. H. Stubbings Co. v. World's Columbian Exposition Co., 110 Ill. App. 210 (1903); Michaud v. McGregor, 61 Minn. 198, 63 N.W. 479 (1895); Abells v. City of Syracuse, supra note 77; Keahon Bros. v. Blank, 161 Misc. 874, 292 N.Y. Supp. 257 (Rockland County Ct. 1936) ; Douglass \& Varnum v. Village of Morrisville, 89 Vt. 393, 95 Atl. 810 (1915). Some cases have rejected this argument. J. M. Griffith Co. v. City of Los Angeles, 54 Pac. 383 (Cal. 1898) (city could not accept work since it was beneath ground); Board of Supervisors v. Patrick, 54 Miss. 240 (1876); Woodruff v. Rochester \& P.R.R., 108 N.Y. 39, 14 N.E. 832 (1888) ; Hall v. Whitney, 165 N.Y. Supp. 838 (Sup. Ct. 1917); Montgomery v. City of Philadelphia, $391 \mathrm{~Pa} .607,139 \mathrm{~A} .2 \mathrm{~d} 347$ (1958). In the Hall case, supra, the architect exchanged a cannon on the owner's yacht for a larger one. The owner told the seller to take it back, but the seller refused. The court held for the owner.

79 Board of Comm'rs v. Hilt, 122 Ind. 215, 23 N.E. 779 (1889); M. DeMatteo Constr. Co. v. Commonwealth, 156 N.E.2d 659 (Mass. 1959) (bridge collapse and potentially dangerous explosion) ; Michaud v. McGregor, supra note 78; Abells v. City of Syracuse, 7 App. Div. 501, 40 N.Y. Supp. 233 (4th Dep't 1896). In this regard it should be noted that article 16 of the AIA contract does not require even an order if property or life is endangered.

${ }^{80}$ Mahoney v, Hartford Inv. Corp., 82 Conn. 280, 73 Atl. 766 (1909) ; Stewart v. Pennsylvama State Camp, 122 Pa. Super. 30, 184 Atl. 476 (1936); Cramp \& Co. v. Central Realty Corp., 268 Pa. 14, 110 Atl. 763 (1920); Cunninghain v. Fourth Baptist Church, 159 Pa. 620, 28 Atl. 490 (1894); Salzner v. Jos. J. Snell Estate Corp., 81 Utah 111, 16 P.2d 923 (1932) (AIA contract). 
(7) Impracticality of giving written order. ${ }^{81}$

(8) Extra work caused by error of the architect. ${ }^{82}$

(9) Architect's refusal to issue written order based upon belief that the work is not extra. ${ }^{83}$

(10) Written order not executed until work was completed with the delay due to architect. ${ }^{84}$

Before an analysis can be made of the factors which have swayed the courts, some theoretical groundwork must be laid. The contract between owner and contractor has created a condition precedent. Before the contractor can recover for extra work, he must obtain a written order. Two theories within the framework of the existing contract may be employed by the contractor to justify recovery for work done without having received a written order. One is that the condition has been excused by waiver. Professor Williston defines true waiver as "a promise, express or implied in fact, when, in reliance thereon action has been taken by the promisee though no consideration is given in exchange for the promise." 85 In other words, the owner must promise expressly or impliedly that he will not demand the writing as a condition to paying for the extra work. If the contractor reasonably relies upon the promise, as by doing the work on an oral order, the promise not to demand the writing will be enforced even in the absence of conventional consideration because of a promissory estoppel. The other

81 Schmulbach v. Caldwell, 196 Fed. 16 (4th Cir. 1912); M. DeMatteo Constr. Co. v. Commonwealth, 156 N.E.2d 659 (Mass. 1959); McGowan v. Gate City Malt Co., 89 Neb. 10, 130 N.W. 965 (1911) (office of prime contractor-defendant located some 500 miles away); McGrath Constr. Co. v. Waupaca-Green Bay Ry., 148 Wis. 372, 134 N.W. 824 (1912).

82 Erskine v. Johnson, 23 Neb. 261, 36 N.W. 510 (1888); R. Lee Tolley Co. v. Marr, 12 Tenn. App. 505 (1931) (dictum). The latter case did not discuss the writing requirement although it involved an AIA contract which required one. The writing requirement was avoided in Gearty v. Mayor of New York, 171 N.Y. 61, 63 N.E. 804 (1902), and Del Genovese v. Third Ave. Ry., 13 App. Div. 412, 43 N.Y. Supp. 8 (1st Dep't 1897), aff'd mem., 162 N.Y. 614, 57 N.E. 1108 (1900), because the extra work was caused by the errors of the engineer and architect, respectively.

83 S. J. Groves \& Sons Co. v. West Va. Turnpike Comm'n, 164 F. Supp. 816 (S.D. W.Va. 1958); Rivercliff v. Linebarger, 223 Ark. 105, 264 S.W.2d 842, cert. denied, 348 U.S. 834 (1954).

84 Bavin \& Burch Co. v. Bard, 81 Cal. App. 722, 255 Pac. 200 (1927); McGrath Constr. Co. v. Waupaca-Green Bay Ry., 148 Wis. 372,134 N.W. 824 (1912). It might appear that the cases cited in this note and note 83 supra are inconsistent with the statement that the architect cannot waive the writing requirement. These cases, however, have other factors which can justify holding for the contractor, so it cannot be stated the holding was based upon acts of the architect. In Groves, supra note 83, the court held no writing was required. In Riverclif, supra note 83 , the architect was part-owner and there had been a course of conduct in paying on oral orders. In Bavin, supra, there was an acceptance of benefits by the owner and in McGrath, supra, there were payments which included the orally ordered extras.

853 WIIITSTON, CoNTRACTS $\$ 689$ (2d ed. 1936). The condition must not be a material par of the agreed exchange. REsTATEMENT, Contracts \& 297 (1932). 
theory is that the parties have assented to the elimination of the writing requirement. This is the contract-modification theory.

Another theory may be used to avoid the writing requirement. But this will turn on a finding that the extra work is the subject matter of a new and separate contract which does not condition the owner's promise to pay on a writing. This theory is similar to that of cases discussed previously. ${ }^{86}$

To compare these theories it will be helpful first to analyze those cases where the work is ordered orally by the owner himself. Finding a waiver, modification, or new contract, the courts now generally hold that the writing requirement will not be a bar if the work is ordered orally by the owner himself. ${ }^{87}$ If the owner ordered the work orally and told the contractor not to worry about the writmg, there is clearly a waiver. If the writing requirement was not mentioned when the work is ordered, an argument might be made for the existence of a new contract. But the parties have made a detailed agreement defining their rights and duties which should control unless the work ordered was either entirely unrelated to the subject matter of the original contract or far beyond its scope. For example, if the owner contracts to pay for a residence, the ordering of more expensive material or adding a garage should come within the original contract if that contract provided that extra work could be ordered. On the other hand, if the owner contracts to pay for a residence and orders a garage be built near another house that he owns or orders two more houses, a new contract might result. Professor Corbin favors the new contract approach, stressing that the fact that the parties have one contract does not prevent them from contracting for other work on different terms. ${ }^{88}$

This theory has a number of difficulties. First, the parties as a rule think they are still operating under the first contract. Second, the parties may not be able to use the general conditions of the original contract to aid in the administration of the performance of the extra work since they will not be incorporated into the new contract. Third, the original contract often provides for a schedule of payment for extra work. The use of the "new" contract method may enable the contractor to obtain more money for the extra work than provided for under the schedule, if the price of labor and materials has risen or if the original contract was bid too low by the contractor.$^{89}$ Both of these possibilities are not uncommon.

86 See notes 49-52 supra.

87 Annot., 66 A.L.R. 649 (1930); Note, 31 ILr. L. Rev. 780 (1937). The leading case is a Holmes opinion, Bartlett v. Stanchfield, 148 Mass. 394, 19 N.E. 549 (1889). For a recent case see Wilson v. Keefe, 150 Cal. App. 2d 178, 309 P.2d 516 (1957).

88 CORBIN, CONTRACTS $\$ 756$ (1951).

80 If the contract sets up a schedule of payments for extra work, on waiver the schedule still applies. Douglass \& Varnum v. Village of Morrisville, 89 Vt. 393, 95 Atl. 810 (1915). But in Mulholland v. Mayor of New York, 113 N.Y. 631, 20 N.E. 856 (1889), the court held directions were not within the contract, so that a writing was not needed and the contract price for work did not control. Cf. Hayden v. City of Astoria, 74 Ore. 525, 145 Pac. 1072 (1915). 
As for modification, this would require that the owner and the contractor both assent to the elimination of the writing requirement from the contract. As a matter of fact this does not happen.

If the work is ordered orally by the owner himself, waiver is most consistent with the facts, leads to a more efficient performance of the contract and prevents the contractor from taking unfair advantage of a rising market.

If waiver is most applicable if the work is ordered orally by the owner himself, certainly it fits those cases where the work is ordered orally by the architect and the basis for recovery is a course of conduct by the owner which, as a rule, falls far short of modifying an existing contract or assenting to a new one. For example, if the owner has paid in the past on oral orders issued by the architect, these acts can be relied upon by the contractor in future situations but hardly form the basis for two parties modifying a contract or entering into a new one.$^{00}$ Also, waiver is more equitable. This conduct does not clearly manifest an implied promise not to demand the written order in the future and the owner should be given the benefit of the doubt by allowing him to retract the waiver before it is relied on. ${ }^{01}$ For these reasons the most accurate analysis will involve the determination of whether the conduct of the owner has given rise to an implied promise that the written order will not be required and whether the contractor reasonably relied upon the promise.

If the contractor relies solely on the architect's oral orders, it is obvious that there is no conduct of the owner which would give rise to an implied promise. If the owner is aware that the architect has consistently disregarded the contract by ordering orally, it may be argued that the owner should have taken steps requiring that the architect abide by the contract. The fact remains that the contractor has proceeded in direct violation of the contract. He has not relied upon anything nor has the owner created

${ }^{90}$ Statutes may make it necessary to consider the theory upon which a holding is based. Some Mechanics' Lien statutes require that building contracts for over a specified sum must be in writing. See, e.g., Colo. Rev. Stat. ANN. § 86-3-1 (1953). If a court uses the new contract theory, such a statute might apply. Perhaps a court might hold it does not bar an action on the debt. If modification is employed, statutes in certain States providing that a written contract can only be modified by a writing or executed oral agreement must be considered. See, e.g., CaI. Crv. Code $\S 1698$. Also, a New York statute provides that if there is a written contract which by its terms requires modifications to be in writing an oral modification is not effective. N.Y. Pers. Prop. Law \& 33 (c) (1). Professor Simpson states that this statute means that even the owner's oral order will not bind him. Simpson, Contracts, 34 N.Y.U.L. REv. 373, 381 (1959). No New York cases have so held. The theory of waiver or new contract might not come within the statute.

91 If the theory employed is waiver, the waiver can be retracted before the contractor has relied thereon. RESTATEMENT, CONTRACTS $\$ 297$ (1932). If the contractor incurs expenses before the retraction, he should recover his out-of-pocket expenses as damages even if he cannot proceed. 
any apparent authority. Since the owner might have prevented the situation from arising, a court might be tempted to require the owner to pay if the court found the work was ordered by the architect and was performed. But the knowledge of the owner as to past orders will not eliminate the question as to whether this particular order was given and whether the work was extra. True, the court could determine these questions, but the purpose of the writing requirement is to obviate these difficult proof problems. Allowing a recovery in this situation would encourage contractors to proceed without a writing and later claim extras, hoping they will be able to convince a jury that the owner knew that the provision was being disregarded.

If the facts go beyond this and indicate that the owner has manifested to the contractor that he knows the architect has been ordering orally, any future oral orders would bind the owner. Here the owner has created apparent authority in the architect to order orally.

Another situation which may arise is the owner's presence at the time the disputed work was allegedly ordered.$^{92}$ Certainly the mere fact of his presence is not a promise to excuse the condition. The architect may issue many orders while supervising. Often the owner has little technical knowledge and does not know an order will involve extra work. If, however, the owner knew or should have known the order involved extra work, and he manifested to the contractor expressly or impliedly his assent to the oral order, the owner should pay for the work. It is the same as if he ordered it.

The most important course of conduct is paying on oral orders, as this is a sufficiently important act to constitute an implied promise upon which the contractor may rely. One act should not be sufficient. A regular pattern should be established before the contractor can rely. Obviously, if the owner pays but states that he will not do so in the future, there is no waiver, as any reliance would not be justified. If payments have been made on oral orders, but before the work in question commenced the contractor is told no more orally ordered work would be paid for, the waiver is retracted and the contractor should not recover even if he does the work. Knowledge of the owner, as in the cases where the owner is present, is significant. The owner should be put on notice in some manner that he is paying for extra work which has been ordered orally. When architects prepare the monthly payment certificates, they customarily state whether any extra work is included. The owner knows whether he has ordered it and usually has received a copy of the order if it has been ordered in writing by the architect. If the certificate expressly includes extra work, the owner usually knows whether he is paying for work ordered orally. His payment means the contractor may rely reasonably and do work ordered orally in the future unless there is a retraction of the waiver before reliance or a warning by the owner at 
the time of payment that orally ordered work would not be paid for in the future. If the owner does not or cannot reasonably be expected to know that he is paying for orally ordered work, any reliance by the contractor would not be reasonable. He is more experienced in these matters, usually presents the certificate for payment and should realize the owner may not know he is paying for orally ordered work.

One case allowed recovery based upon the owner's part payment after the work was completed..$^{93}$ The theory employed was ratification. Ratification may consist of the receipt or retention of benefits with knowledge that the transaction was not authorized. ${ }^{94}$ Since there was no reliance, the case, if it can be justified, must mean that the part payment was an acceptance of the benefits and constituted a ratification. However, the part payment was made routinely with no showing that the owner knew it was payment for extra work. Unless knowledge is present, this should be no ratification. ${ }^{95}$

A number of cases discuss the retention of benefits by the owner, either as a ratification or as a basis for finding unjust enrichment. No case has squarely placed its holding on this factor, but it is usually employed as a makeweight when other factors are present. ${ }^{90}$ There are many obstacles to

93 Abells v. City of Syracuse, 7 App. Div. 501, 40 N.Y. Supp. 233 (4th Dep't 1896).

94 Restatement (Second), Agency \$§ 98, 99 (1958).

95 The dissent in Abells v. City of Syracuse, 7 App. Div. 501, 512, 40 N.Y. Supp. 233, 240-41 (4th Dep't 1896), stressed this point.

${ }^{90}$ In Schmulbach v. Caldwell, 196 Fed. 76 (4th Cir. 1912), aff'd on other grounds, 215 Fed. 70 (4th Cir. 1914), the court stressed that the value of the building was enhanced and a benefit was received, yet also stressed a course of conduct and tle impracticality of giving a written order.

Mention should be made of the cases which hold that a contractor who defaults after part performance may recover in certain situations the net benefit conferred upon the owner. This recovery in restitution is based upon quasi-contractual principles and has, along with the doctrines of substantial performance and divisibility of contracts, been a device by which the courts have been able to avoid a harsh result. See Nordstrom and Woodland, Recovery by Building Contractor in Default, 20 O\#по ST. L.J. 193 (1959). The contractor might contend that these cases are authority for allowing recovery for the architect's oral orders, sinee, though he has breached the contract by not obtaining a written order, he has conferred a net henefit upon the owner. Further, the contractor might point out that in the defaulting contractor cases the same difficult questions of fact will be encountered as in the "extras" cases, since the defaulting contractor will have to show that the work he has done came within the contract. The first objection to this reasoning is that the parties by agrecing to a writing requirement have established a method by which these difficulties of proof are to be avoided. There is no similar provision in the owner-contractor agreement which specifically denies the defaulting contractor the right to recover in restitution for partially completed work. Even thougb the action by the defaulting contractor would be in restitution, such a provision would be given effect since it would be a clear inanifestation that such a risk would be upon the contractor. Also, in the defaulting contractor cases there is no doubt that the work, if within the contract, is desired by the owner and results in a benefit to him. If the owner does not authorize the extra work, it may he that the work is not desired.

Although the test justifiably has been attacked, even in some defaulting contractor cases, recovery has been denied if the breach is wilful. See Nordstrom and Woodland, supra at 
the use of unjust enrichment by reason of a benefit conferred. In building contracts it is difficult to determine whether the work is extra or, stated another way, whether there is any real benefit. This is the precise reason for the writing requirement. If the work is extra, but was ordered orally by the architect without authority from the owner, the owner may contend justifiably that he did not want the work done. In such a case the enrichment may not be unjust. Undoubtedly juries often think it unjust to allow anyone to get something for nothing. Also the modern tendency in the courts is to extend restitutionary methods of preventing unjust enrichment. ${ }^{97}$ Yet it would be more unjust to penalize the owner where the contractor, normally experienced in these matters, takes steps which he knows to be a violation of the terms of the contract. For this reason, retention of benefit and unjust enrichment by themselves have rarely been successful, as in these cases the enrichment, if any, is not unjust.

Ratification by retention of benefits, also, will apply only if the owner could separate the extra work and restore the contractor to status quo. ${ }^{98}$ In the normal building situation this is often difficult. Ratification requires that the owner have a free choice as to whether or not to retain the benefits $^{99}$ and that the owner be aware of the fact that he has retained extra work for which he has not paid. ${ }^{100}$ This may be difficult to show, at least until the demand is made. If the owner is convinced the work was ordered and is extra, he will usually pay. If the owner does not believe the work is extra, retention should not be construed to be a ratification.

Emergency situations and extra work as a result of orders of a building inspector logically fit together. The AIA Standard Contract contains an exception to the writing requirement for certain emergencies. ${ }^{101}$ It might be found the emergency enlarged the authority of the architect, ${ }^{102}$ but the form contract usually covers this situation. Like the retention of benefits, emergency is largely a makeweight.

As to orders of building inspectors, one case was clearly based upon this

211-14. Where the contractor does the work on oral orders of the architect, the owner could contend the breach is wilful.

Finally, and most significantly, recognition of a quasi-contractual recovery for work ordered orally by the architect would make the writing requirement useless. Undoubtedly, quasi-contract has been expanded by the courts. But the writing requirement was developed to avoid specific problems which arose in the industry. Chaos would result in the construction business if contractors were allowed to circumvent the writing clause by suing in quasi-contract.

97 For a recent discussion, see Dawson, Restitution or Damages?, 20 OHro ST. L.J. 175 (1959).

98 Restatement (SeCOND), Agency $\S 99$, comment $c$, illus. 5 (1958).

99 See Seavey, Ratification by Silence, 103 U. PA. L. REv. 30, 38 (1954).

100 Restatement (Second), Agency $\$ 99$ (1958).

101 AIA Standard Contract, art. 12, 16.

102 Restatenent (SeCOND), Agency $\$ 47$ (1958). 
without the other factors which might have supported the decision. ${ }^{103}$ The court seemed to stress the fact that the owner had no legal alternative but to consent to the order. However, there might be an alternative depending upon the powers of the inspector, the nature of the violation and the potential injury to the public. The only time recovery should be allowed because of the orders of a building inspector is when there is danger to persons or property and the owner has no choice but to do the work. In that case, recovery would be based on quasi-contractual principles ${ }^{104}$ since there is an unjust enrichment.

If there is no emergency, the only facts which would justify basing a holding on impracticality of giving a written order would be impossibility of performance, a situation unlikely to occur. Laziness on the part of the architect would not be sufficient. In such a situation the contractor should demand immediate arbitration. ${ }^{105}$

No acts of the architect, unless authorized, should bind the owner. Cases stressing the architect's delay or refusal to issue the writing (based on his belief that the work was not extra) have other factors which are more sig-

103 Cramp \& Co. v. Central Realty Corp., 268 Pa. 14, 110 Atl. 763 (1920). The Pennsylvania cases cited note 80 supra merit some comment. Cunningham v. Fourth Baptist Church, $159 \mathrm{~Pa} .620,28$ Atl. 490 (1894), involved a contract requiring a writing signed by the owner. A building inspector ordered a change, the architect prepared a sketch, and the work was done. The court indicates the owner knew and acquiesced in the change, but stressed the fact that the defendant owner had no option but to provide for the changes ordered for safety's sake. The court concluded with quasi-contract language: "The law imposed on the defendant the duty of seeing that the order was obeyed, and from that arose an obligation to pay those who furnished the necessary material and did the work under the direction of the architect ...." Id. at 622, 28 Atl. at 491. This language is extended in Cramp \& Co. v. Central Realty Corp., supra. There the contract required a writing signed by the architect and a corporate officer. The extras cost over $\$ 12,000$. Even though the contract provided the work was to be done in accordance with city ordinances and under order of proper city officials, which would bave justified binding the owner on express authority in the building inspector, the court followed Cunningham, supra, and stated: "The additional work was made necessary by the order of a public official, acting within the police power of the city and out of consideration for the public safety, and was not a matter as to which either the owner of the builling or the contractor or the architects could exercise an option. The requirement of the official was final and conclusive on all parties, regardless of whether or not an order for the change was signed by the architects ...." $268 \mathrm{~Pa}$. at 19, 110 Atl. at 764. Under article 11 of the AIA Standard Contract, the contractor must notify the architect if the work is contrary to law or ordinances, and the change must be ordered in the same manner as any other change. Articles 12 and 16 give the contractor certain authority to act where there is danger to persons or property.

104 RESTATENIENT, RESTITUTION \$ 115 (1937).

105 Unfortunately, this is not always practical as the contractor is extremely desirous of getting along with the architect. If circuunstances make it inadvisable to assert the contractor's rights in such a situation, after completion he might attempt to recover for the extra work on the theory that the owner, through his architect, breached an implied promise to cooperate. This theory is discussed more fuliy in the text at notes 148-53 infra. None of the "extras" cases lave used this approach. See Spencer, Powers of Direction and Dutermination under Construction Contracts, 41 VA. I. REv. 343, 348-50 (1955), for a discussion of steps that can be taken if the architect refuses to issue a written order. 
nificant in holding the owner liable. ${ }^{105 a}$ When the architect, as interpreter of the contract, has refused to issue an order in the belief that the work is not extra, such a refusal should not aid a contractor in recovering. If the contractor does not agree with the architect, he should demand arbitration whenever the decision of the architect is arbitrable. Like the holding stressing that the extra work was occasioned by errors of the architect, holdings stressing the architect's delay or refusal to issue an order are based on an unstated premise that owners ought to be responsible for the errors of the architect. ${ }^{100}$

Very few of the factors cited by the courts in allowing the contractor to recover withstand legal analysis. Only where a course of conduct of paying on oral orders has constituted a waiver is a holding for the contractor justified. Such a course of conduct should be well established. Isolated or sporadic departures from the contract should not be enough. Knowledge on the part of the owner should be shown clearly. This last requirement may seem hard on the contractor, but his reliance upon the conduct is not reasonable unless he knows the owner has such knowledge. If he is given orders which he believes will involve extra work, he can protect himself by giving a written notice to the owner. He can demand arbitration if the architect insists the work is within the contract.

At this point some reference should be made to certain procedural problems in the "extras" cases. Waiver of the requirement for a written order must generally be pleaded. ${ }^{107}$ However, pleading facts which establish a waiver is sufficient in some jurisdictions, ${ }^{108}$ and failure to object to evidence of the oral order has been held to cure a failure to plead waiver. ${ }^{109}$

Since there are good policy reasons to uphold clauses requiring written orders for extras, there is a heavy burden of proof on the party claiming a waiver. Courts liave required clear and satisfactory proof, ${ }^{110}$ and even clear and convincing proof..$^{111}$

105a See note 84 supra.

106 See text at notes 146-53 infra.

107 Essex v. Murray, 29 Tex. Civ. App. 368, 68 S.W. 736 (1902). See generally 56 AMr. JUR. Waiver $\$ 18$ (1947).

108 C. F. Bolster Co. v. J. C. Boespflug Constr. Co., 167 Cal. App. 2d 143, 334 P.2d 247 (1959). The court stated: "It is settled, however, that this requirement of pleading is satisfied by the allegation of facts which would constitute a waiver .... In the instant case the complaint incorporated the subcontract, including the requirement of a writing in connection with any extra work, and alleged, 'that in addition to the work required to be done by the plaintiff under the terms of the said subcontract, and at the special instance and request of the defendant, the plaintiff applied a levelling coat of cement plaster to the buildings ... This pleading of waiver is sufficient," Id. at 173,334 P.2d at 253. See generally 56 AMr. JUR. Waiver $\$ \S 18,19$ (1947).

109 Benson \& Marxer v. Brown, 190 Iowa 848, 179 N.W. 81 (1920); 56 AMr. JuR. Waiver $\S 19$ (1947).

110 Jefferson Hotel Co. v. Brumbaugh, 168 Fed. 867, 875 (4th Cir. 1909); Campbell BIdg.

Co. v. State Rd. Comm'n, 95 Utah 242, 70 P.2d 857 (1937).

111 James Reilly Repair \& Supply Co. v. Smith, 177 Fed. 168 (2d Cir. 1910); Ashley v.

Henahan, 56 Olio St. 559, 47 N.E. 573 (1897). 
If the waiver which the contractor alleges is based upon the acts of the architect alone, the court itself will decide the issue since only the written contract setting forth the architect's authority is pertinent, and it is within the province of the court to construe the contract. ${ }^{112}$ If the alleged waiver is based upon the acts of the architect and the owner, or the owner alone, it is generally held that waiver is a question of fact for the jury. ${ }^{113}$

The jury should decide whether the oral order was given, ${ }^{113 a}$ as well as whether the work was within the contract. Whether the work was, in fact, done is obviously a jury question.

The majority of the issues in these "extras" cases will be submitted to the jury unless there is a written integrated contract clearly setting forth the architect's authority, or the waiver is predicated entirely upon the acts of the architect without any conduct of the owner which would (1) enlarge the architect's authority, (2) create apparent authority, (3) ratify the unauthorized acts of the architect, or (4) estop the owner from setting up the clause as a defense. Unless the contractor can tie in the owner somehow, he runs the risk of a directed verdict for the owner and may never get a chance at a usually sympathetic jury.

Unquestionably, the building business, like many others, operates largely by oral communications. Jobs must get done and the procedures which would be desirable to an attorney are often lacking. On the other hand, contractors often take the risk of proceeding without written orders with their eyes open and use these claims to attempt to salvage losing contracts. Requiring both architect and owner to sign the order, taking care not to pay on oral orders and making certain the architect issues written orders for extras, would extend the owner's protection.

Courts try to steer a middle course but the inethods they employ are not always analytically sound. The general rule, requiring the writing, will be adhered to, but cases will doubtless arise where equity and fairness demand relief to the contractor. ${ }^{114}$

112 Crane Constr. Co. v. Commonwealth, 290 Mass. 249, 195 N.E. 110 (1935); Iowa Elec. Light \& Power Co. v. Hopp, 221 Iowa 680, 266 N.W. 512 (1936) (AIA contract). Sec also 1 MecheM, AGENCX §§ 294-95 (2d ed. 1914).

113 Ross Eng'r Co. v. Pace, 153 F.2d 35, 49 (4th Cir. 1946) ; Lord Constr. Co. v. United States, 28 F.2d 340 (3d Cir. 1928) ; Mass. Bonding \& Ins. Co. v. Lentz, 40 Ariz. 46, 9 P.2d 408 (1932); C. F. Bolster Co. v. J. C. Boespflug Constr. Co., 167 Cal. App. 2d 143, 334 P.2d 247 (1959); Berg v. Kucharo Constr. Co., 237 Iowa 478, 21 N.W.2d 561 (1946), noted 30 MinN. L. REv. 547 (1946); Camphell Bldg. Co. v. State Rd. Comm'n, 95 Utah 242, 70 P.2d 857 (1937); Douglass \& Varnum v. Village of Morrisville, 89 Vt. 393, 95 Atl. 810 (1915).

113a C. F. Bolster Co. v. J. C. Boespflug Constr. Co., sutpra note 113; Crane Constr. Co. v. Commonwealth, 290 Mass. 249, 195 N.E. 110 (1935).

114 There is one situation in which the contractor should recover on the oral orders of the architect alone: if the architect has authority to order extras in writing, as in the AIA Standard Contract, and if either the owner or the architect admits (a) in writing, or (b) orally, in a court proceeding, that the work was ordered and was extra, the writing requirement should not bar 


\section{Effect of Certain Mechanics' Lien Statutes}

The architect has no authority to enter into a contract on behalf of the owner in the absence of authority beyond that which architects usually possess. Yet, the mechanics' lien statutes of a number of States provide that for their purposes the architect is an agent of the owner. ${ }^{115}$

As construction projects became more complex with subcontractors and materialmen becoming an integral part of the building picture, some method had to be devised to give a security interest to parties who were not in privity with the owner. ${ }^{116}$ Yet, contract theory as the basis for the security interest had to be preserved.

A number of methods were developed. ${ }^{117}$ One creates a statutory agency

recovery. The main purpose of this private statute of frauds is to avoid hitigating these difficult questions. If they are admitted, the writing requirement is a mere technicality. While no cases have so held, some support could be drawn by analogy to the modest number of cases and statutes which deny the defense of the statute of frauds to the party who admits by pleading or in court the making of the contract. AIASKa CoMr. LAws ANN. \$ 58-2-2(4) (Supp. 1958); 2 CoRbIN, Contracts 519 (1950). This is the position of UNIForm Comarercial Code \& 2-201 (3) (b) (1957) (covering only sales of goods). See Note, 38 CorNexr L.Q. 604, 606 (1953).

If the contractor has sufficient bargaining position, which is seldom the case, he might be wise to include the following clause in the contract: If a dispute should arise whereby Owner refuses to pay Contractor for extra work which Contractor in writing asserts was ordered orally by Architect, the writing requirement shall be deened complied with if either Owner or Architect admits in writing or orally at a court proceeding: (1) The work was ordered by Architect, and (2) The work was in fact extra.

115 Ala. Code Ann. tit. 33, \$37 (1940); Ataska Comp. Laws ANn. \$ 26-1-14 (1949); Ariz. Rev. Stat. Ann. \$ 33-981(B) (1956); CaI. Code Civ. Proc. \$ 1182 ; Colo. Rev. Stat. ANn. § 86-3-1 (1953) ; IdaHo Code ANN. \$ 45-501 (1947); Ilu. Rev. Star. ch. \$2, § 1 (1957); Ky. Rev. Stat. \$ 376.010(1) (1956); MD. AnN. Code art. 63, \$11 (1957); Nev. Rev. Stat. \$ 108.020 (1957) ; N.M. STaT. ANN. \& 61-2-2 (1953); ORE. REv. Stat. \$ 87.005(3) (1957); WASH. REv. CoDE $\$ 60.04 .010$ (1958). A typical statute is that of California which states: "For the purposes of this chapter, every contractor, subcontractor, architect, builder or other person having charge of the construction, alteration, addition to, or repair, in whole or in part, of any building or other work of improvement shall be held to be the agent of the owner."

110 The increasing use of surety bonds to handle this problem is discussed in Comment, 68 Y ALE L.J. 138 (1958).

117 Some courts adopt the fiction that, where an owner lets work to a contractor which he sbould be able to tell will involve subcontractors or materialnien, the owner is deemed to have authorized the contractor to do what is necessary to carry out the prime contract. Bangor Roofing \& Sheet Metal Co. v. Robbins Plumbing Co., 151 Me. 145, 116 A.2d 664 (1955); Norton v. Clark, 85 Me. 357, 27 Atl. 252 (1893); W. H. Pipkorn Co. v. Tratnik, 161 Wis. 91, 152 N.W. 141 (1915). Sone States employ devices such as consent and acquiescence. Sirone v. Distefano, 67 So. 2d 150 (La.App. 1953) (owner cannot stand by silently); Jenkins Contracting Co. v. Sixth Ave. \& 57th St. Corp., 282 App. Div. 662, 122 N.Y.S.2d 126 (1st Dep't 1953) (dictum). But see Holland v. Farrier, 75 Ind. App. 368, 130 N.E. 823 (1921) (more than mactive consent required); Osborne v. McGowan, 1 App. Div. 2d 924, 149 N.Y.S.2d 781 (3d Dep't 1956) (mere acquiescence and benefit not enough). Others enacted the statutory presumption that an owner has authorized the improvement if he was aware of it and posted no notice of non-responsibility within a certain period of time. Cat. Cone Crv. Proc. \$1183(1) (b) (within 10 days); MINN. Star. $\$ 514.06$ (1957) (within 5 days); Ore. Rev. Star. \$ 87.030 (1957) (within 3 days); S.D. ConE $\$ 39.0706$ (Supp. 1952) (within 5 days). 
in the contractor or subcontractor, so that parties who furnish material or services under contract with these parties can acquire a lien. These statutes often added "architect" or "some other person in charge." 118

Jurisdictions having these statutes still hold that entering into a contract is beyond the architect's customary authority. ${ }^{110}$ Only rarely have these statutes been used successfully to create a lien where the work has been ordered by the architect. ${ }^{120} \mathrm{~A}$ study of the statutes and cases discloses a number of reasons for the infrequent use of these provisions. First, the statutes do not purport to affect public buildings. Secondly, the statutes themselves have a great many inherent limitations: notices required; $;^{121}$ the lien limited to work covered by the contract between owner and contractor; $;^{122}$ the amount of the lien limited to the contract price between owner and contractor ; ${ }^{123}$ and, in some States, the owner permitted to enter into a no-lien contract with the contractor. ${ }^{124}$

In addition to these limitations, the courts have added others. Oregon, which has had the greatest amount of litigation in this area, holds the prime contractor is customarily "in charge." ${ }^{125}$ An architect may be placed "in

118 See statutes note 115 supra.

110 It should be noted that these statutes create only a security interest and not a personal obligation. McClain v. Hutton, $131 \mathrm{Cal}$. 132, $61 \mathrm{Pac} .273$, modified on other grounds, $131 \mathrm{Cal}$. 132, 63 Pac. 622 (1900); Schram v. Manary, 123 Ore. 354, 260 Pac. 214, 262 Pac. 263 (1927); McCormick v. Bertschinger, 115 Ore. 250, 237 Pac. 363 (1925). Yet, even where the action is brought to enforce a mechanics' lien, these same courts will hold that the architect does not have power to bind in contract. The Arizona statute raises a peculiar problem. A firm line of cases held the statute created no personal liability. Keefer v. Lavender, 74 Ariz. 24, 243 P.2d 457 (1952); Harbridge v. Six Points Lumber Co., 17 Ariz. 339, 152 Pac. 860 (1915). The court in the latter case stressed the inclusion in the statute of the words "under the terms lereof." The present statute no longer contains that phrase. The author was unable to find a session law which amended the Arizona statute to eliminate "under the terms hereof." In 1956 the Arizona Revised Code was enacted, and one suspects the deletion was made by the revisors to chiminatc a redundancy. It is doubtful that the intention was to permit personal liability to be created by the statutory agent.

120 Hornlein v. Bohlig, 37 Cal. App. 646, 174 Pac. 697 (1918) (architect hired firm to do engineering designs). See Bennett v. Ascher, 228 Ill. App. 350 (1923), where the court using doubtful reasoning concluded a structural engineer could not be a lien claimant. See also Ohio Oil Co. v. Smith-Haggard Lumber Co., $288 \mathrm{Ky} .278,156$ S.W.2d 111 (1941), which by a dictum recognized that the architect might subject the building to a hen without being a counnon law agent.

121 AJaska Comp. Laws Anv. § 26-1-5 (1949); Cal. Code Crv. Code $\$ 1193.1$; Colo. Rev. Stat. ANN. § 86-3-9 (1953); Ky. Rev. Stat. § 376.010(3) (1956); MD. Ann. Code art. 63, § 11 (1957); WASH. REv. CODE $\S 60.04 .060$ (1958).

122 CaL. Code Civ. Proc. $\$ \$ 1185.1$ (a), (b).

123 E.g., CaL. Code Civ. Proc. § 1185.1; Ky. Rev. Stat. 3376.010 (1956).

124 IrI. REv. StaT. ch. 82, § 21 (1957).

125 Smith v. Wilcox, 44 Ore. 323, 74 Pac. 708, 75 Pac. 710 (1903). The court stated: "To facilitate the acquisition of the lien, however, the statute lias made the origimal contractor an agent of the owner while in charge of the construction. Necessarily, he is given the primary control thereof ... the parties may agree that an architect ... shall be in charge, but unless there is some such provision to shift the supervision he is necessarily entrusted with it." (Emphasis added.) Id. at 326, 74 Pac. at 709. 
charge," however, and if he is he becomes the owner's statutory agent. ${ }^{126}$ The prime contractor usually has authority to engage the subcontractors and materialmen. It is doubtful whether an architect with limited supervisory responsibility would be held to be "in charge." Only in the rare situation where the arclitect is given authority to take over the supervisory responsibilities of the contractor will he be "in charge" so as to make him the statutory agent. The one case basing a recovery upon statutory agency of the architect did not discuss his supervisory duties, although it appears that he had normal responsibilities. ${ }^{127}$ Another court-made limitation, developed in California, is that the statute merely creates a rebuttable presumption of agency. ${ }^{128}$

While these statutes appear to modify the rule that an architect normally has no power to bind the owner in contract, legislative and judicial limitations have curtailed their use to a large degree. It is unlikely that the statute is used and is too clear to require litigation. Instead, the limited

126 Smith v. Wilcox, supra note 125 . Consistent with this is a holding that before the main contract was let, the architect could not be a statutory agent as there would not be anything to be in charge of. Litherland v. S. Morton Cohn Real Estate \& Inv. Co., 54 Ore. 71, 100 Pac. 1, 102 Pac. 303 (1909). See also McCormack v. Bertschinger, 115 Ore. 250, 237 Pac. 363 (1925); Beach v. Stamper, 44 Ore. 4, 74 Pac. 208 (1903) ; Fitch v. Howitt, 32 Ore. 396, 52 Pac. 192 (1898). For a comprehensive discussion see Galen, Mechanics' Liens in Oregon, 29 ORE. L. REv. 308 (1950). In a recent Colorado case, Hayutin v. Gibbons, 338 P.2d 1032 (Colo. 1959), the work was ordered by the contractor. The court stated that the contractor was not the statutory agent because he was not "in charge."

127 Hornlein v. Bohlig, 37 Cal. App. 646, 174 Pac. 697 (1918).

128 Jurgenson v. Diller, 114 Cal. 491,46 Pac. 610 (1896) ; Donohoe v. Trinity Consol. Gold \& Silver Mining Co., 113 Cal. 119, 45 Pac. 259 (1896). It is submitted that the judicial emasculation of the statute was due to the holding in Santa Cruz Rock Pavement Co.v. Lyons, $117 \mathrm{Cal}$. 212, 48 Pac. 1097 (1897), which held unconstitutional a statute making the reputed owner a statutory agent. Fear of this constitutional difficulty originally may have forced the court to construe the statute as merely evidentiary. The problem became complicated when the court held in 1900 that a statutory agent could create only a hen, not a personal obhgation. McClain v. Hutton, 132 Cal. 152, 61 Pac. 273, modified on other grounds, 131 Cal. 132, 63 Pac. 182 (1900). If inerely creating a presumption was the result of the statute, a failure to overcome it should logically lead to a common law agency and corresponding personal liability on the part of the owner. Yet in Street v. Hazzard, 27 Cal. App. 263, 149 Pac. 770 (1915), the court affirmed its holding as to the evidentiary nature of the statute and held no lien would exist if the claimant knew the agent would be the sole person to whom he could go for wages. $C f$. Whittier v. Puget Sound Loan, Trust \& Banking Co., 4 Wash. 666, 30 Pac. 1094 (1892), which held no hen where the claimant thought the agent was the principal. Yet 3 years after the Street case, the California court in Hornlein v. Bollig, 37 Cal. App. 646, 174 Pac. 697 (1918), found a lien without discussing presumptions. Perhaps there was no evidence to overcome the presumption. The typical building contract, which was involved in Hornlein, however, does not give authority to the architect to enter into contracts. If the statute creates a mere presumption, it would be almost meaningless. As a rule, a prime contractor has authority without the statute to enter into subcontracts. 
number of cases is due to lack of compliance with technical requirements ${ }^{120}$ and the "in-charge" requirement.

In "extras" cases these statutes are of limited value. If extra work is ordered in writing, there is no problem; ${ }^{130}$ if ordered orally, there would be no recovery under the statute, for in most States the contract price is the ceiling for the lien or the lien extends only to work authorized in the original contract. The contractor still has to prove the work was extra and was ordered.

Mechanics' lien statutes were enacted when the building industry was in its infancy. The Maryland statute was enacted in $1838^{131}$ and the others enacted between 1868 and $1900 .{ }^{132}$ They were meant to protect those parties not in privity with the owner, and the architect was made a statutory agent along with the contractor and subcontractor in order to cover all possibilities. Also, the statutes were developed in a new frontier economy where the contractor and architect often were the same person. ${ }^{133}$ These provisions in the mechanics' lien statutes were not intended to change the general rule that the architect has no authority to enter into or modify a contract, and the interpretation given them by the courts has not changed the basic rule.

II

LIABILITY OF OWNER FOR CONDUCT OF ARCFITECT WHICH RESULTS

IN ADDED EXPENSE TO THE CONTRACTOR

\section{A. Owner-Contractor Agreement as Easis for Recovery}

When the owner hires an architect, the latter agrees, in exchange for the owner's promise to pay a fee, to draw plans and specifications, to get bids and award contracts, and generally to supervise the work. Supervisory duties may involve the issuance of certificates upon which progress payments and the final payment are based, ${ }^{134}$ checking to see that the building is going up according to plans and specifications, ${ }^{135}$ and performing the

129 Lakeview Drilling Co. v. Stark, 210 Ore. 306, 310 P.2d 627 (1957); Barr v. Lynch, 163 Ore. 607, 97 P.2d 185 (1940). See Benson v. Stenger, 337 P.2d 338 (Ore. 1959), where material was ordered by the contractor, and the main contention of the plaintiff materialmen was that the contractor was a common law agent. The majority was unconvinced. The statute was not mentioned.

130 In Kentucky the order by the statutory agent must be in writing anyway. Kr. REv. STAT. \$ 376.010 (1956).

$131 \mathrm{Md}$. Laws 1838 , ch. $205, \S 9$. This applied to Baltimore, and by 1860 the provision was statewide. MD. CoDE art. 61, $\$ 11(1860)$.

132 Ala. Laws 1895, No. 570, § 1; Ataska Crvm Code ch. 28, § 262 (1900); Ariz. Terr. Laws 1885, No. 93, $₹ 1$; Cal. Stat. 1868, ch. 448, Act of Mar. 30, 1868 (repealed by California Civil Code of 1872, reenacted by Cal. Stat. 1873-74, ch. 586, § 1); Colo. Laws 1899, ch. 118, § 1; Idaho Laws 1893, ch. 1; IIl. Laws 1895, Act of June 26, 1895, §1; Ky. Laws 1896, ch. 29, §1; Nev. Laws 1875, ch. 64, § 1; N.M. Laws 1880, ch.77, § 2; Ore. Laws 1885, p. 13, §1; Wash. Laws 1877, p. 219, § 19.

133 See Boswell v. Laird, 8 Cal. 469, 68 Am. Dec. 345 (1857).

134 AIA Standard Contract, arts. 24-26.

135 Id., arts. $13,21,38,39$. 
duties assigned by the contract so that the building goes up smoothly and with a minimum of confusion. ${ }^{138}$

If the architect fails to exercise due care in the performance of these duties, the contractor may incur added expense. In many such cases, the contractor will seek to reimburse himself from the owner. The following acts performed negligently by the architect have led to litigation by the contractor against the owner:

(1) Inadequate or faulty plans. ${ }^{137}$

(2) Delay in furnishing plans, specifications or detailed drawmgs. ${ }^{138}$

(3) Delay in passing on detailed drawings submitted by the contractor for the architect's approval. ${ }^{139}$

(4) Improper supervision, which may consist of failure to coordinate work properly or giving improper directions. ${ }^{140}$

Cases where the negligence of the architect consists of drafting faulty or defective plans will not be covered in the text. ${ }^{141}$

136 Id., arts. $3,5,38,39$.

137 See, e.g., Northern Pac. Ry. v. Goss, 203 Fed. 904 (8th Cir. 1913) ; Myers Constr. Co. v. Wood River Drainage \& Levee Dist., 221 Ill. App. 473 (1921) ; Erskine v. Johnson, 23 Neb. 261, 36 N.W. 510 (1888) ; M. L. Ryder Bldg. Co. v. City of Albany, 187 App. Div. 868, 176 N.Y. Supp. 456 (3d Dep't 1919) ; Mason Tire \& Rubber Co. v. Cummins-Blair Co., 116 Ohio St. 554, 157 N.E. 367 (1927) ; R. Lee Tolley Co. v. Marr, 12 Tenn. App. 505 (1931); Lonergan v. San Antonio Loan \& Trust Co., 101 Tex. 63, 104 S.W. 1061 (1907) ; Adams v. Tri-City Amusement Co., 124 Va. 473, 98 S.E. 647 (1919); Bentley v. State, 73 Wis. 416, 41 N.W. 338 (1889). 138 Selden Breck Constr. Co. v. Regents of Univ. of Mich., 274 Fed. 982 (E.D. Mich. 1921); Morgan v. Town of Burlington, 316 Mass. 413, 55 N.E.2d 758 (1944). Shoemaker v. Riebe, $241 \mathrm{~Pa}$. 402, $88 \mathrm{Atl} .662$ (1913), involved an unusual variation on this theme. Here a subcontractor unsuccessfully sued the prime contractor on the claim that he was delayed by the architect's failure to furnish detailed plans on time.

139 Mosler Safe Co. v. Maiden Lane Safe Deposit Co., 199 N.Y. 479, 93 N.E. 81 (1910); Berry v. Huntington Masonic Temple Ass'n, 80 W. Va. 342, 93 S.E. 355 (1917).

140 Hudgins v. Hann, 240 Fed. 387 (5th Cir. 1917); Campbell v. Lunsford, 83 Ala. 512, 3 So. 522 (1887) (direction of work); Burke v. Ireland, 166 N.Y. 305, 59 N.E. 914 (1901); Mulholland v. Mayor of New York, 113 N.Y. 631, 20 N.E. 856 (1889) (engineer's directions); Del Genovese v. Third Ave. Ry., 13 App. Div. 412, 43 N.Y. Supp. 8 (1st Dep't 1897), aff'd mem., 162 N.Y. 614, 57 N.E. 1108 (1900); Mason Tire \& Rubber Co. v. Cummins-Blair Co., 116 Ohio St. 554, 157 N.E. 367 (1927) (interrupting contractor's access to work); First Sav. \& Trust Co. v. Milwaukee County, 158 Wis. 207, 148 N.W. 1093 (1914) (foolish and unnecessary orders).

141 If the architect furnishes faulty plans causing the contractor extra expense, the contractor may claim that: (1) his own deviation is not a breach and the owner has no cause to discharge him, R. Lee Tolley Co. v. Marr, 12 Tenn. App. 505 (1931); (2) the error furnished consideration to support an oral agreement by the owner to pay for extra work, United Steel Co. v. Casey, 262 Fed. 889 (6th Cir. 1920); (3) the requirement that extras be ordered in writing is inapplicable, Erskine v. Johnson, 23 Neb. 261, 36 N.W. 510 (1888); cf. Gearty v. Mayor of New York, 171 N.Y. 61, 63 N.E. 804 (1902); Del Genovese v. Third Ave. Ry., supra note $140 ;(4)$ he is entitled to damages for the extra expense incurred, see 24 Cornenc L.Q. 109 (1938); 35 KY. L.J. 232 (1947); 21 MINN. L. REv. 70 (1936); 5 OKLA. L. REV. 480 (1952).

Often, in an attempt to avoid the writing requirement for extras, the contractor will claim 
Before discussing the cases on the other points, some mention must be made of the patterns of contracting that an owner may employ in erecting a building. In the "single contract" system, the owner lets a contract to the prime contractor who may delegate various parts of the work to subcontractors. There is no privity between owner and subcontractor and each must deal with the prime contractor. ${ }^{142}$ In the "separate contract" system, ${ }^{143}$ the owner contracts individually with each contractor who is to work on the building. In a partial use of this system, the owner lets a contract to a "main contractor" who puts up the shell of the building and the owner also contracts directly with the major trades such as the electrical contractor and the plumbing and heating contractor. ${ }^{144}$

the extra expense was due to faulty plans or misrepresentations as to soil conditions, borings or other facts. See Furton v. City of Menasha, 71 F. Supp. 563 (E.D. Wis. 1947). Despite carefully drawn protective language explicitly stating the specifications are estimates and not warranties, and despite a requirement that the bidder check these conditions, contractors are occasionally successful. See law review notes cited supra. They may prevail if they have been given no time to check the representations and have relied reasonably. Of course, it must be slown the data are representations and not estimates. The contractors also have a cliance if the protective and cautioning language is not sufficiently clear. Pennsylvania 'Turnpike Comm'n v. Smith, 350 Pa. 355, 39 A.2d 139 (1944). Better drafting defeated the contractor in Montgomery v. City of Philadelphia, 391 Pa. 607, 139 A.2d 347 (1958). The last two cases present a good study of how a slight variation in language can cause contrary results.

142 See Continental Ill. Nat'l Bank v. United States, 112 Ct. Cl. 563, 81 F. Supp. 596 (1949). Here the Court of Claims (one judge dissenting) reluctantly refused to permit a subcontractor to sue the United States because of lack of privity. The majority invited legislation to meet the problem. See 34 MinN. L. REv. 143 (1949); 1 MERCER L. REv. 117 (1949). The woes of govern. ment subcontractors have been explored recently. See Penne, Legal Remedies of the Government Subcontractor, 32 So. CAL. L. REv. 1 (1958). Third party beneficiary law may be the wedge which will allow a subcontractor to sue the owner. See Brown v. Bowers Constr. Co., 236 N.C. 462, 73 S.E.2d 147 (1952), for a successful use of third party principles in an action by lessee against a subcontractor.

143 "If it often works badly to entrust everything to one contractor, perhaps sometbing may be gained by a partial return to the old system of separate contracts, letting the more difficult and critical branches, such as plumbing, heating and ventilation, electrical work and elevators to contractors whose own forces actually execute the work. Such a system is very largely in use." American Instirute of Archrtects, Archtrectural Practice 50 (7th ed. 1953). In commenting on the system of letting all work to separate contractors, the authors of this work state, at page 51: "It is obvious that the duties falling on the Architect under the separate contract system are much heavier than when the work is let under a single contract . . . . [I]nstead of guiding and supervising the work of one Contractor whose duty is to bring the Sub-Contractors into cooperation, the Architect must guide the work of the Contractors for all the trades, harmonize their operations, be vigilant that they and their materials are ready when needed, see that they employ as large a force as can properly work, and settle differences between them. ... He must himself be at the building more frequently than is ordinarily the case. While this procedure saves the Owner the profit on the entire work, to which the General Contractor is entitled, on the other hand, simce many of the Contractor's duties devolve upon the Architect, he must be paid for them. The Institute's 'Forms of Agreement between Owner and Architect' ... therefore provide for an additional remuneration to the Architect when the separate contract system is employed."

144 This partial use of the separate contract system is employed frequently in large jobs, and in a number of States it must be used in public contracts that excecd a certain amount. See, e.g., N.Y. State Fnv. Law $\$ 135$ (over $\$ 25,000.00$ ); OHro Rzev. Code ANw. $\$ 153.03$ (Baldwin 1958) (over $\$ 1,000.00$ ); Wrs. Stat. $\S 66.29(6)$ (1957). 
In cases involving both public (which often have a private architect) and private contracts, the courts have held the owner liable where the errors of the architect have caused the contractor additional expense in doing the job. Some cases look at the contract between the owner and the contractor. Where that contract imposes certain duties on the architect, his failure to perform them properly is charged to the owner. ${ }^{145}$ Even where the contract between the owner and the contractor has not placed expressly certain duties upon the architect, the courts have filled in the gaps by implying promises by the owner not to hinder, interfere or delay, ${ }^{146}$ to keep the work in such a state of forwardness that the contractor may do the work in the most economical manner, ${ }^{147}$ and to coordinate the work with the other con-

145 Selden Breck Constr. Co. v. Regents of Univ. of Mich., 274 Fed. 982 (E.D. Mich. 1921) (duty to furnish plans and drawings on time); Morgan v. Town of Burlington, 316 Mass. 413, 55 N.E.2d 758 (1944) (duty to make new plans); Mosler Safe Co. v. Maiden Lane Safe Deposit Co., 199 N.Y. 479, 93 N.E. 81 (1910) (duty to approve detail drawings); Del Genovese v. Third Ave. Ry., 13 App. Div. 412, 43 N.Y. Supp. 8 (1st Dep't 1897), af'd mem., 162 N.Y. 614, 57 N.E. 1108 (1900) (duty to direct and supervise contractors); Shore Bridge Corp. v. State, 186 Misc. 1005, 61 N.Y.S.2d 32 (Ct. Cl. 1946) (duty to approve plans); Berry v. Huntington Masonic Temple Ass'n, 80 W. Va. 342, 93 S.E. 355 (1917) (duty to pass on shop drawings); cf. Guthrie v. Carpenter, 162 Ind. 417 , 70 N.E. 486 (1904). This rationale is best illustrated by the following statement of the Massachusetts court in Morgan v. Town of Burlington, supra at 417,55 N.E.2d at 760 . "[T] he contract expressly provided that in performance of the work the architect was to be the personal representative of the defendant ... [T] he change in plans was an essential part of the work that he was employed to do on behalf of the town ... [I]n the performance of this particular detail of the work he was not acting in any dual capacity, or as any arbiter or in behalf of the plaintiff. We think that $m$ respect to this change in the plans the architect was the agent of the defendant, and that the latter was liable for his unreasonable delay."

The stress on his function as agent is significant in the actions against the architect by the owner for negligently issuing a certificate. Mr. Justice (then Judge) Holmes stated that in performing this act the architect is liable as an agent and does not have a quasi-judicial immumity. Corey v. Eastman, 166 Mass. 279, 44 N.E. 217 (1896). With respect to supervisory duties, he is more obviously an agent. Palmer v. Brown, 127 Cal. App. 2d 44, 273 P.2d 306 (1954).

146 Hart v. American Concrete Steel Co., 278 Fed. 541 (E.D.N.Y. 1921) ; Gearty v. Mayor of New York, 171 N.Y. 61, 63 N.E. 804 (1902) (city engineer); M. L. Ryder BIdg. Co. v. City of Alhany, 187 App. Div. 868, 176 N.Y. Supp. 456 (3d Dep't 1919) ; Del Genovese v. Third Ave. Ry., 13 App. Div. 412, 43 N.Y. Supp. 8 (1st Dep't 1897), aff'd mem., 162 N.Y. 614, 57 N.E. 1108 (1900); Goodrum v. State, 158 S.W.2d 81 (Tex. Civ. App. 1942). A similar duty is owed by prime contractor to subcontractor. Walter R. Chffe Co. v. DuPont Eng'r Co., 298 Fed. 649 (D. Del. 1924); Nelson v. Pickwick Associated Co., 30 Ill. App. 333 (1889) ; Norcross v. Wills, 198 N.Y. 336, 91 N.E. 803 (1910) ; Edward E. Gillen Co. v. Jolın H. Parker Co., 170 Wis. 264, 171 N.W. 61, mandate modified, 174 N.W. 546 (1919).

147 Brucker v. Manistee \& G.R.R., 166 Mich. 330, 130 N.W. 822 (1911) (engineer-employee of defendant) ; Shore Bridge Corp. v. State, 186 Misc. 1005, 61 N.Y.S.2d 32 (Ct. Cl. 1946) (State engineer); Erickson v. Edmonds School Dist., 13 Wash. 2d 398, 125 P.2d 275 (1942) (dictum). A case of doubtful logic holding no such imphed promise was Brooker Eng'r Co. v. Gravel River Dam Authority, 144 F.2d 708 (10th Cir. 1944).

There are numerous cases where the owner has been held for the delay caused by failure of another contractor to do his work on time. Annot., 115 A.L.R. 65 (1938). For representative cases see Stehlin-Miller-Henes Co. v. City of Bridgeport, 97 Conn. 657, 117 Atl. 811 (1922); 
tractors. ${ }^{148}$ Using these techniques, the courts have held the owner impliedly promises that the contractor shall have access to the work ${ }^{140}$ and that the work will be laid out in an orderly fashion. ${ }^{150}$ When the owner is found to have this duty, the courts usually call the architect the agent of the owner and decide that the failure of the architect to perform the act with due care places liability upon the owner. ${ }^{151}$ Another approach found in some of the cases is to hold without a discussion of the status of the architect that nonperformance is simply a breach by the owner. ${ }^{152}$ The owner's procurement of a promise by the architect to perform does not enable the owner to shed ultimate responsibility for the failure of the promised performance to occur. In effect, the owner promises expressly or impliedly that the architect will perform. ${ }^{153}$

Cases using agency language raise doctrinal difficulties. The fact that the error which caused pecuniary damage was made by the person given authority to perform the act does not mean recovery is based on agency principles. While it may be dangerous to generalize on what true agency

Shore Bridge Corp. v. State, supra; Byrne v. Bellingham Consol. School Dist., 7 Wash. 2d 20, 108 P.2d 791 (1941). The significance of these cases is that the delay of plaintiff contractor caused by another contractor may be traceable to the neghigent supervision of the architcct if the duty of the owner through his architect is to coordinate the work of the various contractors and he has not made reasonable efforts to do so. This implied promise has also heen found where the general contractor is sued by the subcontractor. Frank T. Hickey, Inc. v. Los Angeles Jewish Community Council, 128 Cal. App. 2d 676, 276 P.2d 52 (1954); J. J. Brown Co. v. J. C. Simmons Co., 2 Ill. App. 2d 132, 118 N.E.2d 781 (1954).

148 United States v. Blair, 321 U.S. 730, rehearing denied, 322 U.S. 768 (1944) (by implication); Jefferson Hotel Co. v. Brumbaugh, 168 Fed. 867 (4th Cir. 1909); Visintine v. New York, C. \& St. L.R.R., 160 N.E.2d 311 (Ohio 1959).

In Anthony P. Miller, Inc. v. Wilmington Housing Authority, 165 F. Supp. 275 (D. Dcl. 1958), the contract bad an express requirement of coordination on the part of the owner. A contractor contended this was hreaclied when the owner let to a non-union contractor. The contention was unique but unsuccessful.

149 Del Genovese v. Third Ave. Ry., 13 App. Div. 412, 43 N.Y. Supp. 8 (1st Dep't 1897), aff'd mem., 162 N.Y. 614, 57 N.E. 1108 (1900); Mason Tire Co. v. Cummins-Blair Co., 116 Ohio St. 554, 157 N.E. 367 (1927).

150 Hart v. American Concrete Steel Co., 278 Fed. 541 (E.D.N.Y. 1921) ; Brucker v. Manistee \& G.R.R., 166 Mich. 330, 130 N.W. 822 (1911).

151 Morgan v. Town of Burlington, 316 Mass. 413, 55 N.E.2d 758 (1944); Mosler Safe Co. v. Maiden Lane Safe Deposit Co., 199 N.Y. 479, 93 N.E. 81 (1910).

152 Hart v. American Concrete Steel Co., 278 Fed. 571 (E.D.N.Y. 1921); M. L. Ryder Bldg. Co. v. City of Albany, 187 App. Div. 868, 176 N.Y. Supp. 456 (3d Dep't 1919). Even these cases may not entirely avoid agency language. In the $R y d e r$ case, the court stated: "[T]he acts and directions of an architect or engimeer relating to the details of construction over which they have charge are the acts of their principal and that when by their acts or directions a contractor is so obstructed in his work that extra materials and labor are required to be furnished by him, in order that he may fulfill his contract, there is a breacl of contract on the part of the owner...."Id. at 871, 176 N.Y. Supp. at 459. (Emphasis added.)

153 Section 2 of the Restatement of Contracts (1932) provides that a person may promise that something will occur in the future even though the pronisor will not do it or has no control over the occurrence of the event. 
liability is, an attempt will be made to use the building contract to distinguish the proper use of agency from a spurious one. A building contract may give the architect authority to approve shop drawings submitted by the contractor if they are in accordance with the contract. ${ }^{154}$ If the architect approves them, the contractor may proceed with the work. He need not fear the owner will refuse to pay since the decision of the architect will bind the owner if the architect acted within his authority. Even if the owner would not have approved them, the act of the architect is the act of the owner. This is a true use of the principles of agency. The contract may go on to state, or the court may imply, a promise by the owner that the architect will pass on the drawings within a reasonable time after submission. ${ }^{155}$ If the architect takes an unreasonable time to do so, the contractor should recover from the owner not because approval was within the scope of the architect's authority but because the owner has promised the contractor that the architect will pass on them within a reasonable time.

Since the architect is generally considered an agent of the owner, it is understandable low courts have carelessly employed agency language in these cases. But assume that the owner attempts to discharge his obligation to coordinate the work by obtaining a promise from the "main contractor" to coordinate the other separate contractors instead of having this done by the architect. This is sometimes done at the request of the architect who desires to relieve himself of a vexatious task. If the main contractor does not coordinate, the owner should be liable to the injured separate contractor based upon the contract between owner and injured separate contractor. ${ }^{156}$

154 AIA Standard Contract, art. 5.

105 Ibid.

156 If the aggrieved contractor is a separate contractor there may be other reasons for still holding the owner. The injured contractor is not in privity with the main contractor and may not be able to recover from him. The courts are not likely to leave him without a remedy, so recovery will be given against the owner. Although there are signs that the doctrine of privity is weakening with respect to actions by one separate contractor against another, the use of third party theories usually means a period of uncertainty while the courts explore the various tests and their attendant fictions. For successful actions by one separate contractor against another see M. T. Reed Constr. Co. v. Virginia Metal Prods. Co., 213 F.2d 337 (5th Cir. 1954) (apparently involving an AIA Standard Contract); Visintine \& Co. v. New York, C. \& St. L.R.R., 160 N.E.2d 311 (Ohio 1959); Southwest Gen. Constr. Co. v. Price, 267 S.W.2d 855 (Tex. Civ. App. 1954); see State ex rel. Nat'l Surety Corp. v. Malvaney, 221 Miss. 190, 72 So. 2d 424 (1954) (action against architect for issuing certificate without proof contractor had paid his bills). But see American Pipe \& Constr. Co. v. Harbor Constr. Co., 51 Wash. 2d 258, 317 P.2d 521 (1957), where the court refused to allow a contractor to sue a pipe supplier on the latter's contract with the city. The Visintine case, supra, contains an indirect recognition that these are contract questions only. There, the court held that the injured separate contractor was a third party beneficiary of the owner's contract with another, nonperforming, contractor. The court stated that the owner obtained the promise to discharge the obligation owed by the owner to the injured separate contractor. Visintine \& Co. v. New York, C. \& St. L.R.R., supra at 313. 
In this situation the court would be hard pressed to use agency language. ${ }^{167}$ The theoretical basis of recovery proved a problem where the contractor suffered pecuniary damage due to faulty plans. The courts could not call the architect an agent as there were a number of cases involving personal injuries which held that as to plans the architect was an independent contractor. ${ }^{158}$ Instead they allowed recovery against the owner for the architect's faulty plans on the theory that the owner warrants to the contractor the sufficiency of the plans. ${ }^{150}$ Where the plaintiff-contractor and the defendant-owner have set forth their rights and duties in a contract, the courts have confused the issue by needlessly resorting to agency rationale, ${ }^{100}$ thus providing fodder for briefs in future cases where the issues are different.

It would serve no useful function to catalog recoverable items of damages in the text. ${ }^{161}$ However, attempts by the owner to limit liability to

157 The issue whether these cases are based upon agency or contract could be vital if the added expense were caused by an engineer or architect who is retained by the principal architect to aid in a certain portion of the work. It is common for an architect to retain such assistants as, e.g., a landscape architect, structural engineer or heating engineer in large jobs. If the contractor sues the owner for added expense, it will be more difficult to call the consultant an agent of the owner. The courts conceivably could call the consultant a subagent. For a penetrating discussion of these problems see Seavey, Subagents and Subservants, 68 HARv. L. REv. 658 (1955), in Restatement (SeCOND), Agency, app. at 25 (1958).

158 Looker v. Gulf Coast Fair, 203 Ala. 42, 81 So. 832 (1919) (action by contractor's employee based upon faulty plans); Boswell v. Laird, 8 Cal. 469 (1857) (nearby landowner's property flooded due either to faulty plans or to construetion); Prest-0-Lite Co. v. Skeel, 182 Ind. 593, 106 N.E. 365 (1914) (action by contractor's employee based on faulty plans); White v. Green, 82 S.W. 329 (Tex. Civ. App. 1904) (action by adjacent landowner based on faulty plans); 3 Ax. JUR. Architects $\$ 5$ (1936); Annot., 19 A.J.R. 1168 at 1182 (1922).

159 See law review notes, supra note 141.

160 See, e.g., Paxton v. County of Alameda, 119 Cal. App. 2d 393, 259 P.2d 934 (1953).

161 In M. L. Ryder Bldg. Co. v. City of Albany, 187 App. Div. 868, 176 N.Y. Supp. 956 (3d Dep't 1919), the court allowed the value of additional work and materials furnished. Other cases went further. In Seglin-Harrison Constr. Co. v. State, 264 App. Div. 466, 35 N.Y.S.2d 940 (3d Dep't 1942), the court found the State's acts caused plaintifi contractor an 11-month delay. The court allowed recovery both for certain cost items and for profit. The court of clains had earlier in this case disallowed office overhead such as director's fees, office salaries, postage, telegrams and other miscellaneous office expenses. Seglin-Harrison Constr. Co. v. State, 30 N.Y.S.2d 673 (Ct. Cl. 1941). In Hart v. American Concrete Steel Co., 278 Fed. 541 (E.D.N.Y. 1921), the court allowed, among other things, recovery for (1) increased labor costs, (2) superintendent's services, (3) suspension of work of steain shovel, and (4) idleness of men. In Shore Bridge Corp. v. State, 186 Misc. 1005, 61 N.Y.S.2d 32 (Ct. Cl. 1946), the court allowed recovery for enforced idleness of contractor's plant, machinery and equipment. Inflation played a role in H. J. McNeel, Inc. v. Canyon County, 76 Idaho 74, 277 P.2d 554 (1954), where the plaintiff successfully claimed "mcreases in wage scales for labor, cleaning of steel on hand and additional steel, straightening of foundation forms which had become warped ...."Id. at 77, 277 P.2d at 555. See generally Spencer, Powers of Direction and Determination Under Construction Contracts, 41 VA. L. REV. 343, 350-52 (1955), for discussion of daunages.

Sometimes the contractor completes the job on time even though he claims be could have completed it earlier except for the delays caused by the owner. In United States v. Blair, 321 U.S. 730, rehearing denied, 322 U.S. 768 (1941), the Supreme Court did not allow damages in such a case. In Shore Bridge, supra, which did not involve otber contractors, the Blair case was distinguished on the ground it involved a claim that the United States failed to get the other contractors to cooperate. 
extensions of time merit some comment. Public contracts usually contain a clause which restricts the contractor to an extension of time where delay is caused by the government and does not permit the contractor to recover damages. These clauses are upheld, but equities on the part of the contractor have led to a number of exceptions. ${ }^{162}$ In private contracts, the courts struggled indecisively for a time with the question of whether a provision for an extension of time impliedly denied the contractor a right to sue for damages. ${ }^{103}$ The AIA Standard Contract, following the majority of the cases, permits the contractor to sue for damages despite the presence of the extension clause. ${ }^{164}$

Some mention should be made of the independent contractor rule. That venerable rule, or what is left of it, absolves the employer from liability for torts committed by the imdependent contractor unless one of the many exceptions to the rule is available. ${ }^{165}$ For many purposes the architect is

162 Psaty \& Fuhrman Inc. v. Housing Authority, 76 R.I. 87, 68 A.2d 32 (1949). The exceptions which have been developed, largely in New York, involve: (1) concealment, (2) misrepresentation, (3) fraud, (4) direct interference (most often used), or (5) delay caused before performance began. The cases are collected in Annot., 10 A.L.R.2d 801 (1950); 24 CoRNELI L.Q. 109 (1938); 35 KY. L.J. 232 (1947); 21 MINN. L. Rev. 70 (1936); 5 OHIA. L. REv. 480 (1952).

Often government contracts attempt to protect against a claim for unforeseen expenses by providing not only that such risks are upon the contractor, discussed note 141 supra, but that only an extension in time will be given for unforeseen difficulties. Such language was unsuccessful in James Pilkington Co.v. City of New York, 211 App. Div. 558, 560, 207 N.Y. Supp. 118, 120 (1st Dep't 1924), aff'd mem., 243 N.Y. 638, 154 N.E. 638 (1926), where the court stated that "ingenuity of drafting has not yet succeeded in covering every sort of liability which may arise ... as a result of which extra work is necessary." The court held the event was so far beyond contemplation of the parties that the contract provisions did not apply. A recent discussion of this problem is found in A. Kaplen \& Son, Ltd. v. Housing Authority, 42 N.J. Super. 230, 126 A.2d 13 (App. Div. 1956).

103 For cases holding an extension clause does not bar an action for damages see SeldenBreck Constr. Co. v. Regents of Univ. of Mich., 274 Fed. 982 (E.D. Mich. 1921); W. H. Stubbings Co. v. World's Columbian Exposition Co., 110 Ill. App. 210 (1903); Del Genovese v. Third Ave. Ry., 13 App. Div. 412, 43 N.Y. Supp. 8 (1st Dep't 1897), aff'd mem., 162 N.Y. 614, 57 N.E. 1108 (1900) ; Byrne v. Bellingham Consol. School Dist., 7 Wash. 2d 20, 108 P.2d 791 (1941), purporting to distinguish Goss v. Northern Pac. Hospital Ass'n., 50 Wash. 236, 96 Pac. 1078 (1908). Contra, Haydnville Mining \& Mfg. Co. v. Art Institute, 39 Fed. 484 (C.C.N.D. IIl. 1889) ; Richard v. Clark, 43 Misc. 622, 88 N.Y. Supp. 242 (Sup. Ct. 1904) (some stress on contract himit at $\$ 1,000)$; Goss v. Northern Pac. Hospital Ass'n, supra.

The provision for time extension was held not to be an exclusive remedy in several cases where subcontractor was suing prime contractor. Nelson v. Pickwick Associated Co., 30 Ill. App. 333 (1889) ; Edward E. Gillen Co. v. John H. Parker Co., 170 Wis. 264, 171 N.W. 61, modified, 174 N.W. 546 (1919). As can be expected, "waiver" rears its many-faced head in these cases. Accepting extension beld not to be waiver: Selden-Breck Constr. Co. v. Regents of Univ. of Mich. supra; Byrne v. Bellinghan Consol. School Dist., supra. Contra, Hansen v. Covell, 218 Cal. 622, 24 P.2d 772 (1933).

164 AIA Standard Contract, arts. 18, 31.

105 Restatement, Torts $\$$ 409-29 (1934); Restatement (Second), Agenct $\$ 214$ (1958). In Pacific Fire Ins. Co. v. Kenny Boiler \& Mfg. Co., 201 Minn. 500, 503, 277 N.W. 226, 228 (1937), the court made the famous statement, "it would be proper to say that the rule is now 
considered an independent contractor. ${ }^{166}$ The owner, indeed, may feel that he should not have to pay for the errors of a licensed, professional person whom he selected with care and with whom he did not interfere. ${ }^{100 a}$ But these actions by the contractor against the owner are in contract. ${ }^{107}$ Even though the breach may have been caused by the neghigence of the archi-

primarily important as a preamble to the catalog of its exceptions." See Comment, 44 CarIr. L. REv. 762 (1956), for a discussion of the exceptions in California. Even if the cases now being discussed were tort actions, they could be explained by the convenient exception for nondelegable duties created by contract. RestaTEMIENT (SECOND), AgENCY \$ 214, comment $d$ (1958); Prosser, Torts 352 (2d ed. 1955).

100 The traditional tests for determining who is an independent contractor would place the architect in that category. Restatearent (SECOND), AgENCy $\$ 220$ (1958). Where it is necessary for other purposes to determine the architect's status, the courts have held that he is an independent contractor. Metcalf \& Eddy v. Mitchell, 269 U.S. 514 (1926) (exemption as State cmployee under federal tax); Mitchell v. Lublin, McGaughy \& Associates, 358 U.S. 207 (1959) (architect conceded not an employee for purposes of Wages and Hours Law); New Independent Tobacco Warehouse v. Latham, 282 S.W.2d 846 (Ky. 1955) (architect not employee under workmen's compensation); Stephens County v. J. N. McCammon, Inc., 122 Tex. 148, 52 S.W.2d 53 (1932). Also, a number of cases, using tests similar to those employed in determining whether an individual is an independent contractor, have held the cluties of an architect were nondelegable. Monahan v. Fitzgerald, 164 III. 525, 45 N.E. 1013 (1897); Clark v. Bird, 46 Ill. App. 583 (1892); Smith \& English v. Board of Educ., 115 Kan. 155, 222 Pac. 101 (1924); Louisville Foundry \& Mach. Co. v. Patterson, 93 S.W. 22 (Ky. App. 1906). But see American Trust Co. v. Coryell, 3 Cal. 2d 151, 43 P.2d 1102 (1935) (certain minor tasks delegable by to qualified subordinates). The Kansas court in Smith \& English v. Board of Educ., supra at 157, 222 Pac. at 101, stated: "The business of an architect has the dignity of a learned profession. A competent architect is a person of peculiar skill and taste. He must be a man of culture, of disciplined mind, artistic eye and trained hand."

166a Telling the contractor to pursue the architect is not practical. The contractor's effeetive pressure hes in cessation of work if the contract is breached. Obviously no contractor will continue work while attempting to recover from the architect. To keep thimgs going on a construction job the owner must assume the risk as to the acts of the architect.

Even after the job is completed, there are cogent reasons for charging the owner with the errors of his architect. The owner and the contractor have the most at stake. Disputes relating to the job should be resolved between them. The fact that the actions complamed of are caused by a nominally independent contractor does not change this. The possibility of poor supervision is a normal risk incident to putting up a building. The owner should bear this risk, especially since he selects the architect.

The parties to this complex undertaking realize this, and the AIA Standard Owner-Contractor Agreement specifically provides that certain mistakes of the architect will be paid for by the owner. Article 13 provides that if the architect orders work uncovered for inspection and it is determined that the work did comply with the contract, the owner will pay the cost of re-exaunination or replacement. Article 15 obligates the owner to pay for extra work ordered in writing by the architect without authority. Article 18 provides the contractor may obtam an extension of time if he is delayed by the architect. It should be noted in this regard that article 18 specifically mentions the architect while article 31 dealing witl actions for damages merely states each party is responsible for the acts of its employees.

167 It is true that a plaintiff may sue in tort where there las been misfeasance even if there would also be an action in contract. Prosser, The Borderland of Tort and Contract, SELEcted TOPICS ON THE LAW OF TORTS 402-22 (1954). But the courts may bold that if the damage is pecuniary as opposed to physical the gravamen is in contract. Id. at 433-50. 
tect, ${ }^{108}$ the rights and duties were established expressly or impliedly by the owner-contractor agreement. Without it there could be no action. ${ }^{169}$

\section{B. Courses Open to the Owner if Sued}

In the cases discussed above, the owner has a cause of action against the architect only if the latter has breached his contract with the owner. The owner must not lose sight of the fact that the duty which the contractor claims was owed him was created by the contract between owner and contractor. The claim against the architect must be based upon the contract between owner and architect. Unless the owner can find that the architect undertook to perform these duties under the owner-architect contract, the owner may find himself in the unhappy position of losing both ways.

Assuming the owner does have a claim over against the architect, which is usually the case, whether the owner asserts this claim in the contractor's action against the owner depends in the first instance on whether the procedure statutes in the jurisdiction where he is sued allow him to do so. Also, obtaining personal service may be a problem if the architect is a nonresident and the statutes and "doing-business" cases do not permit constructive service on the architect. ${ }^{170}$ Even if it is possible for the owner to assert the claim

168 The problem of privity may make it difficult for an injured contractor to sue the archi tect. It is true that privity is weakening in cases where personal injuries occur after the acceptance of the building by the owner. PROSSER, TORTS 519 (2d ed. 1955).

Recent cases allowing personal injury actions against the negligent party after acceptance by the owner are: Hanna v. Fletcher, 231 F.2d 469 (D.C. Cir.), cert. denied, 351 U.S. 989 (1956), 261 F,2d 75 (D.C. Cir. 1958), cert. denied, 359 U.S. 912 (1959) ; Tomchik v. Julian, 171 A.C.A. 152, 340 P.2d 72 (1959); Slavin v. Kay, 108 So.2d 462 (Fla. 1959). Contra, E. I. DuPont de Nemours \& Co. v. Kissinger, 259 F.2d 411 (5th Cir. 1958) ; Reynolds v. Manley, 223 Ark. 314, 265 S.W.2d 714 (1954), noted 10 ARK. L. Rev. 152 (1955); Watts v. Bacon \& Van Buskirk Glass Co., 20 Ill. App. 2d 164, 155 N.E.2d 333 (1958) ; Hartford v. Coolidge-Locher Co., 314 S.W.2d 445 (Tex. Civ. App. 1958), noted 37 Tex. L. Rev. 354 (1959); cf. Peak v. Richmond Elementary School Dist., 161 Cal. App. 2d 366, 326 P.2d 860 (1952) (action by adjoining landowner against architect for improper supervision); see Annot., 59 A.L.R.2d 1072 (1958) ; 19 LA. L. REv. 221 (1958). Privity is also losing much of its vitality in the contract actions. See cases note 156 supra, where one separate contractor has been able to sue another separate contractor. But as yet no cases have allowed a contractor to sue the architect based upon the latter's faulty supervision.

169 As an example, seller may hire an independent contractor trucker to deliver goods to buyer. The contract between seller and buyer may provide that delivery is to be made on January 1. If the driver of the truck takes a wrong turn and arrives on January 15, seller is hable to buyer for breach of contract. If, on the other hand, the trucker backs up negligently and injures buyer who is standing near the dock, seller is not liable to buyer. In the first case the rights and duties are created by the contract; in the second, by the law. In the contract action it makes no difference how seller intended to perform. All that matters is that the promised performance fails to occur.

170 If the owner retains substantial fees due the architect, the latter may be forced to come into the owner's jurisdiction to bring action for the money, thus allowing the owner to make service. Along this same line, a contractor might justify jurisdiction over a nonresident architect by garnishing fees in the hands of the owner due the architect. 
over against the architect in the same action, there is little use, if the judgment is uncollectible, in asserting the claim and taking a clance of antagonizing a witness upon whose testimony and cooperation so much of the owner's case depends. ${ }^{171}$

If the architect is financially responsible and the statutes permit the assertion of the clain in the same action, the owner should do so. All the issues will be decided in one lawsuit. If the owner loses to the contractor, he will also take a collectible judgment against the architect, provided only the owner can show the architect has breached the owner-architect contract.

It is possible that the owner's action against the architect will be brought separately. The owner nuust be aware of certain dangers and take steps to avoid them in the event of a separate action.

These cases are often very close on the issues of negligence and the extent of damages. It is not niconceivable that a jury in the first case night find the architect neghigent while a second jury night come to a contrary result. Also, the second jury night find lower damages even if they found the architect negligent. Juries often favor contractors in these actions, especially if the contractor is local. Also, the second suit niay very well be in the architect's home area and the plaintiff owner may be an outsider. ${ }^{172}$

Unfortunately for the owner, these issues will not be res judicata in the second case since the architect was not a party to the first action. ${ }^{173}$ Even if the architect testifies as an expert witness and aids the owner in preparing for trial by furnishing technical advice, this will not be sufficient to fall within the exception to the "same parties" rule for participants in an action who are not parties. ${ }^{174}$ There is one step the owner may take to attempt to

171 If the owner has an option of asserting his claim against the architect in the first action or in a subsequent one, to sonne degree the wise choice will be determined by the personality of the architect. Asserting the claim-over in the first action will not endear the owner to the architect; but if enough of the architect's money is involved or if losing the case may mean a cancellation of liability insurance, he may defend his conduct vigorously. However, many architects are by temperament highly individualistic, and their reactions in these situations may be unpredictable. The owner slould always consider just what effect the assertion of the claim-over will lave on his architect, for it may be that it will not be worth the risk of receiving lukewarm cooperation from the architect and sharply increasing the chances of losing to the contractor. Actions against architects in these cases have been relatively rare. See Frank Coluccio Constr. Co. v. Kitsap County Sewer Dist., 52 Wash. 2d 776, 329 P.2d 189 (1958). The increased use of liability insurance by architects undoubtedly will change this.

172 In addition to these difficulties, the owner who has to relitigate the questions of negligence and damages will have to depend for his evidence to some degree upon the contractor, who, having obtained his judgment, may be disinclined to be cooperative.

173 30A Axr. JUR. Judgments $\$ 393$ (1958). It is often stated that a principal has a right of indemnification against an agent whose liability he discharges. However, the judgment against the principal in the action by a third party is not conclusive against the agent unless the agent was a party to that action, participated therein or did not defend in the first action after being notified to defend by the principal. REstatenient, JudGMEnTs $\$ \$ 106-07$ (1942). For a collection of cases on giving notice, see Note, 44 Iowa L. REv. 542, 555 (1959).

174 The cases on what constitutes participation in the action are collected in Annot., 139 A.L.R. 9 (1942). 
avoid this dilemma. The principal, if sued as a result of the acts of his agent, can notify the agent to defend the action. ${ }^{175}$ If the agent does defend, the issues decided in the first action will be res judicata in the action by the principal against the agent. ${ }^{176}$ If the agent does not defend after notice, and the principal loses after a good faith defense, the principal can sue for legal expenses and the issues decided in the first action are res judicata between principal and agent. ${ }^{177}$ The only questions to be decided in the second action will be whether the legal expenses in the first case were reasonable and who was responsible as between owner and architect. ${ }^{178}$ This would mean a determination of whether the architect has breached his contract with the owner.

\section{Methods by Which the Ozner Can Minimize His Risk}

Some of the premises underlying decisions holding owners for the errors of their architects are less valid today. Courts today are more likely to allow a damaged party to sue the architect directly. ${ }^{179}$ Architects are financially more responsible. ${ }^{180}$ But many of the other reasons for holding the owner are still meaningful. It is unlikely that the owner will be able to shed

175 The point might be raised that this use of the agency label is not consistent with the previous statement that such cases are really based on contract notions. Nevertheless, most cases characterize the architect as an agent, and for this reason agency language and authorities are used.

17630 A AM. JUR. Judgments $\$ 401$ (1958).

177 REstateNeNt (SECOND), AGENCY $\S 399$, comment $h$ (1958); 30A AM. JUR. Judgments $\S 417$ (1958).

178 Several objections to this method of avoiding relitigation of these issues might be made. The architect might contend (1) that he is not an agent for this purpose, and (2) that the architect was not liable to the contractor due to lack of privity.

The contention that he is not an agent is without merit. It is clear that the rule is grounded upon the owner's indemnification right. RESTATEMIENT, REstitution \$76 (1937). While many cases have involved principal and agent, the rule is not dependent upon the establishment of such a relationship. The claim that the owner is discharging an obligation which is not the architect's also bas shortcomings. First, it is not at all certain that lack of privity would prevent the contractor from suing the arclitect directly. Cases cited note 156 sufra; cf. State ex rel. Nat'I Surety Corp. v. Malvaney, 221 Miss. 190, 72 So. 2d 424 (1954). A more fundamental objection to this contention is that its underlying premise is that the indemnity theory requires that the contractor be able to sue the architect. The only requirement is that as between owner and architect the arclitect should pay. This determination is inade by an interpretation of the ownerarchitect contract. In discussing when an indemnity exists, the Restatement says: "The rule ... applies when two or more persons are subject to a duty to a third person either as joint promisors or otherwise, under such circumstances that one or more of them, as between themselves, should perform it rather than the other." REsTatearent, RestrTution $\$ 76$, comment $b$ (1937). (Emphasis added.) The duty need not be created by a promise to the contractor, but can be created by a promise to the owner.

170 See cases cited notes 156,168 supra.

180 In large measure this is due to the increased use of "errors and omissions" liability policies by architects. 
the ultimate responsibility. ${ }^{181}$ If there is any change, the courts will probably allow the contractor to sue the architect as well as the owner. ${ }^{182}$

There are certain precautionary measures which the owner can take to protect his claim over against the architect and to ensure that it is adjudicated in the same action if he is sued by the contractor.

First, the owner must not engage his architect by a casual oral arrangement. The supervisory duties of the architect as set forth in the ownercontractor agreement should be compared with the promises made by the arclitect in his contract with the owner. There should be no areas where the owner-contractor agreement requires acts of the architect which are not clearly covered in the owner-architect agreement. The duties of the architect are very vague in the latter type contract. ${ }^{183}$ If it is desired to keep the agreement short, incorporation by reference may be used.

Second, the owner should be certain that the claim over will be collectible. He should require the architect to carry and maintain insurance for the duration of the job and a reasonable time thereafter. ${ }^{184}$ The insurance should be paid for in advance for this period in order to avoid any possibility that the policy will not be in force for failure to pay premiums. Since these policies usually can be cancelled for a failure to give notice, the owner should make certain that notice is given if a claim is made. ${ }^{185}$ If the architect has the duty of coordinating separate contractors, the owner should consider retaining until completion of the building a larger percentage of the architect's fee than is provided for in the AIA Standard Contract, ${ }^{188}$

181 The owner could obtain a promise from the contractor that he will sue only the architect in the event he is caused extra expense by errors of the architect. There are any number of practical reasons why such a method is not likely to be used. A discussion of these problems would be beyond the scope of this article.

182 In Inman v. Binghamton Housing Authority, 3 N.Y.2d 137, 143 N.E.2d 895 (1957), and in Hanna v. Fletcher, 231 F.2d 469 (D.C. Cir.), cert. denied, 351 U.S. 989 (1956), 261 F.2d 75 (D.C.Cir. 1958), cert. denied, 359 U.S. 912 (1959), plaintifis sued owner, contractor and architect. In Southwest Gen. Constr. Co. v. Price, 267 S.W.2d 855 (Tex. Civ. App. 1954), plaintiff contractor sued both the owner and another separate contractor.

183 AIA Form A-102, Agreement hetween Owner and Architect, arts. 1, 7 (6th ed. 1953).

184 The owner should check his contingent liability policy to ensure that it covers him in the event he is hable for extra expenses incurred by the contractor. Article 28 of the AIA' Standard Contract provides that the owner may maintain contingent liability insurance to cover damages for bodily injury and other damage against which the contractor is required to insure. Article 27 requires the contractor to insure against bodily injuries. But see PARKER AND ADAMrs, AIA Standard Contract Forms and tBe Law 51 (1954), where it seems to be assumed that extra expense clains would be covered under the hability insurance requirements of articles 27 and 28.

${ }^{185}$ If possible, the owner should see to it that he reccives all notices and copies of all correspondence pertaining to the policy.

186 Under article 5 of the AIA Form A-102 contract between owner and architect, the architect receives $75 \%$ of the fee before commencing to put up the building. The remaining $25 \%$ is paid in proportion to the work rendered. If the architect sets an extra $4 \%$ in such contracts, as is suggested by article 3 of the AIA Form Contract, B-102, the suggestion may ba unnecessary. 
especially if the architect is a nonresident. If a claim is made against the owner based upon acts of the architect, the owner should not release any fee due the architect, especially if the owner is going to assert a claim over. However, he should not retain an unreasonable amount in light of the amount of the claim.

Third, the owner must be certam he will be able to obtain personal service on the architect if he uses a nonresident architect. The statutes on constructive service should be checked to see if they are broad enough and the "doing-business" cases must be analyzed. If there is any. doubt, the owner should require the architect to appoint an agent for service of process. ${ }^{187}$

Fourth, the owner should extract an express promise on the part of the architect to appear and defend any action upon notification by the owner that the contractor is suing the owner based upon the acts of the architect. ${ }^{188}$ While this is restating the common law, an express provision would refute any argument by the architect that the common law does not apply.

Unquestionably the use of all these measures may not be palatable to the architect. He may argue that all these protective measures indicate a lack of confidence in him which will be mimical to a proper architect-client relationship. Much will depend upon the relative bargaining positions. The owner's attorney may find that his most difficult task is convincing his client that these measures are necessary. Owners making their first venture into the building business are invariably optimistic, at least at the beginning of the job.

\section{CONCLUSION}

The courts have zealously protected the owner when the issue has been whether certain acts have been within the scope of the architect's authority. This authority has been carefully limited and narrowly construed. In so doing, the courts have recognized that the contractor is usually more experienced in these matters and can protect himself by making certain that the architect possesses the authority which he is attempting to exercise.

187 If this is done care should be taken not to appoint a fictitious agent such as the secreretary of state. While such a method was allowed in Green Mountain College v. Levine, $120 \mathrm{Vt}$. 332, 139 A.2d 822 (1958), noted 59 CoruMr. L. REv. 530 (1959), its use would be dangerous and should be avoided.

188 The owner already does this with respect to potential claims by a separate contract against the owner based upon the acts of another separate contractor. AIA Standard Contract, art. 34. In this regard, if the claim turns out to be invalid the owner agrees to pay for the cost of the defense. The owner ought to consider whether such a clause should specifically state that failure to defend would make the issues decided in the first case res judicata in any subsequent action. If this were not spelled out, a failure to appear and defend might be a breach only, and then the owner would have to prove damages. It would seem that the danage would be any amount which the owner had to pay in the first action less whatever was recovered in the second action. But agam it would be safer to spell it out and avoid the question. 
On the other hand, where the acts or failure to act by the architect have caused the contractor added expense, the owner is liable if the owner has promised expressly or impliedly that the architect would perform. These results are desirable despite the apparent status of the architect as an independent contractor for other purposes. The policy arguments in the scope of authority cases are usually inapplicable where the architect's negligent performance or his failure to perform his duties under the owner-contractor agreement has resulted in added expense to the contractor. Instead, the complex building enterprise demands the owner be responsible for the acts of his architect. A recognition of his potential liability for the acts of his architect should cause the owner to insure that he will have a valuable claim over against the architect which, statutes permitting, he will be able to assert in any action brought against him by the contractor based upon the acts of the architect. 